\title{
Multiple Orbitoides d'Orbigny lineages in the Maastrichtian? Data from the Central Sakarya Basin (Turkey) and Arabian Platform successions (Southeastern Turkey and Oman)
}

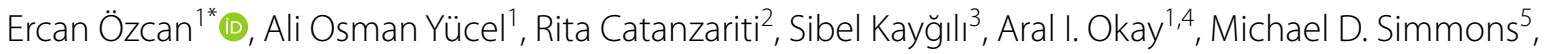
Johannes Pignatti ${ }^{6}$, iftikhar Ahmed Abbasi ${ }^{7}$ and Ümitcan Erbil ${ }^{4,8}$

\begin{abstract}
The standard reconstruction of species of Orbitoides d'Orbigny into a single lineage during the late Santonian to the end of the Maastrichtian is based upon morphometric data from Western Europe. An irreversible increase in the size of the embryonic apparatus, and the formation of a greater number of epi-embryonic chamberlets (EPC) with time, is regarded as the main evolutionary trends used in species discrimination. However, data from Maastrichtian Orbitoides assemblages from Central Turkey and the Arabian Platform margin (Southeastern Turkey and Oman) are not consistent with this record. The Maastrichtian Besni Formation of the Arabian Platform margin in Southeastern Turkey yields invariably biconvex specimens, with small, tri- to quadrilocular embryons and a small number of EPC, comparable to late Campanian Orbitoides medius (d'Archiac). The upper Maastrichtian Taraklı Formation from the Sakarya Basin of Central Turkey contains two distinct, yet closely associated forms of Orbitoides, easily differentiated by both external and internal features. Flat to biconcave specimens possess a small, tri- to quadrilocular embryonic apparatus of Orbitoides medius-type and a small number of EPC, whereas biconvex specimens possess a large, predominantly bilocular embryonic apparatus, and were assigned to Orbitoides ex. interc. gruenbachensis Papp-apiculatus Schlumberger based on morphometry. The flat to biconcave specimens belong to a long overlooked species Orbitoides pamiri Meriç, originally described from the late Maastrichtian of the Tauride Mountains in SW Turkey. This species is herein interpreted to be an offshoot from the main Orbitoides lineage during the Maastrichtian, as are forms that we term Orbitoides 'medius', since they recall this species, yet are younger than normal occurrence with the accepted morphometrically defined lineage. The consistent correlation between the external and internal test features in 0 . pamiri implies that the shape of the test is not an ecophenotypic variation, but appears to be biologically controlled. We, therefore, postulate that more than one lineage of Orbitoides exists during the Maastrichtian, with a lineage that includes O.'medius' and O. pamiri displaying retrograde evolutionary features.
\end{abstract}

Keywords: Orbitoides, Maastrichtian, Morphometry, Central Sakarya Basin, Arabian Platform margin, Turkey

Editorial handling: Elke Schneebeli

*Correspondence: ercanozcan034@yahoo.com; ozcanerc@itu.edu.tr

${ }^{1}$ Department of Geological Engineering, Faculty of Mines, İstanbul

Technical University (iTU), Maslak, 34469 İstanbul, Turkey

Full list of author information is available at the end of the article

\section{Introduction}

Orbitoides d'Orbigny is an orbitoidal larger foraminifer that thrived in the tropical and sub-tropical shallow marine carbonate platforms and ramps from Central America to Asia during the late Santonian to the end of the Maastrichtian (Goldbeck \& Langer, 2009; Loeblich \& Tappan, 1987; van Gorsel, 1978). The genus evolved from 
a simple test, consisting of solely an equatorial layer with a small embryonic apparatus and a few epi-embryonic chamberlets (EPC), to large tests with thick lateral layers on both sides of the equatorial layer, large embryons and many epi-embryonic chamberlets. A single evolutionary succession of species (from oldest to youngest: Orbitoides hottingeri van Hinte, Orbitoides douvillei (Silvestri), Orbitoides tissoti Schlumberger, Orbitoides medius (d'Archiac), Orbitoides megaloformis Papp and Küpper, Orbitoides gruenbachensis Papp, Orbitoides apiculatus Schlumberger, and Orbitoides gensacicus (Leymerie)) has been constructed, ranging from the late Santonian or early Campanian to the end of the Maastrichtian (Caus et al. 1996; Eggink \& Baumfalk, 1983; van Gorsel, 1978; van Hinte, 1966a, 1968, 1976). Recently, Albrich et al. (2014) interpreted Orbitoides sanctaepelagiae (Astre) as a valid species and considered it as a transitional form between $O$. hottingeri and O. douvillei.

The Maastrichtian part of the Orbitoides lineage was constructed mainly from data gathered from the Maastrichtian type section in the Netherlands and some sections in SW France and Spain. It, therefore, more properly represents the evolution of the genus in Western Europe. The exact stratigraphic distribution of the species within this lineage is not yet precisely calibrated against the standard geologic time scale. In spite of these uncertainties, three species, O. gruenbachensis, O. apiculatus and O. gensacicus, have commonly been reported from Maastrichtian sediments. These species correspond to an advanced developmental stage of the presumed lineage and are characterised by a relatively large embryonic apparatus (the size of which is expressed by $\mathrm{Li}+\mathrm{li}$ ) and many epi-embryonic chamberlets (expressed by E, the total number of primary and accessory epi-embryonic chamberlets (EPC)).

It is noteworthy that specimens with rather small embryons and a small number of epi-embryonic chamberlets (morphometrically in the range of the Campanian species $O$. medius) have been reported associated with the 'advanced' members of the genus within Maastrichtian strata (Baumfalk, 1986; Baumfalk \& Willemsen, 1986; Eggink \& Baumfalk, 1983; Görmüş \& Meriç, 2000; Özcan \& Özkan-Altıner, 1997). Most of these studies do not consider typologically different specimens as separate species, but rather assume a single species is present, following the morphometric species concept where all specimens from one population receive the same species name. According to the morphometric approach, morphologic characters of the majority of the specimens in a population are also considered to be more important for species determination than the characters of the individual specimens (Drooger, 1993; van Gorsel, 1978; van Hinte, 1966b). This means that variations in test features such as shape, features of lateral layers, chamberlets and piles are explained by variations in environmental conditions, and are not considered to possess taxonomic value in species discrimination (see van Gorsel, 1978 for discussion).

Having recognised two morphologically distinct groups of tests of Orbitoides during outcrop-based studies of the upper Maastrichtian Taraklı Formation in Nallhhan region (Central Turkey), we carried out a detailed study to record embryonic-nepionic developmental stages, paying special attention to external test features. In addition to the well-known species $O$. ex. interc. gruenbachensis-apiculatus, we show that these late Maastrichtian populations include predominantly flat- to biconcave specimens, possessing small, tri- to quadrilocular embryonic apparatus of Orbitoides medius-type and a small number of EPC, previously recorded from southern Turkey as O. pamiri, but not known from Europe. We also present unpublished data of EÖ from the Maastrichtian Besni Formation from the Arabian Plate margin, previously assigned to Orbitoides 'medius' in the frame of his $\mathrm{PhD}$ studies (Özcan, 1994). For further context, Orbitoides from the upper Maastrichtian Beyobası Formation of the Haymana Basin (Central Turkey) and upper Campanian-Maastrichtian Qahlah and Simsima Formations of Oman are also discussed briefly, with the overall aim of testing the hypothesis that more than one evolutionary lineage of Orbitoides occurs within the Maastrichtian.

\section{Geological setting, stratigraphy and larger foraminiferal assemblages \\ Central Sakarya Basin (Central Turkey)}

The Jurassic-Cretaceous Central Sakarya Basin is located in the Sakarya Zone of the Pontides (Okay \& Tüysüz, 1999). The sedimentary sequence begins with Lower Jurassic conglomerates, sandstone and shales, which unconformably overlie a Variscan and Cimmeride basement (Ocakoğlu et al. 2019; Saner, 1980). The Lower Jurassic siliciclastic rocks are overlain by Upper Jurassic to Lower Cretaceous limestones, no younger than Aptian (Altıner et al. 1991). The Albian to Santonian sequence is represented by sandstone, shale, pelagic limestone and marl. Siliciclastic turbidite deposition begins in the Campanian and extends into the Maastrichtian (Ocakoğlu et al. 2019). These turbidites, the Yenipazar Formation (Saner, 1980), have a thickness of more than $1000 \mathrm{~m}$ and form a regressive sequence. Turbidites pass up into massive marls, the Seben Formation (Saner, 1980), which grades into 'neritic' sandstones of the Taraklı Formation (the focus of our study), recording the final stage of extensive Cretaceous marine sedimentation in the Central Sakarya Basin (Saner, 1980) (Fig. 1a and b). The palaeogeographic position of the basin is shown in Fig. 2. 


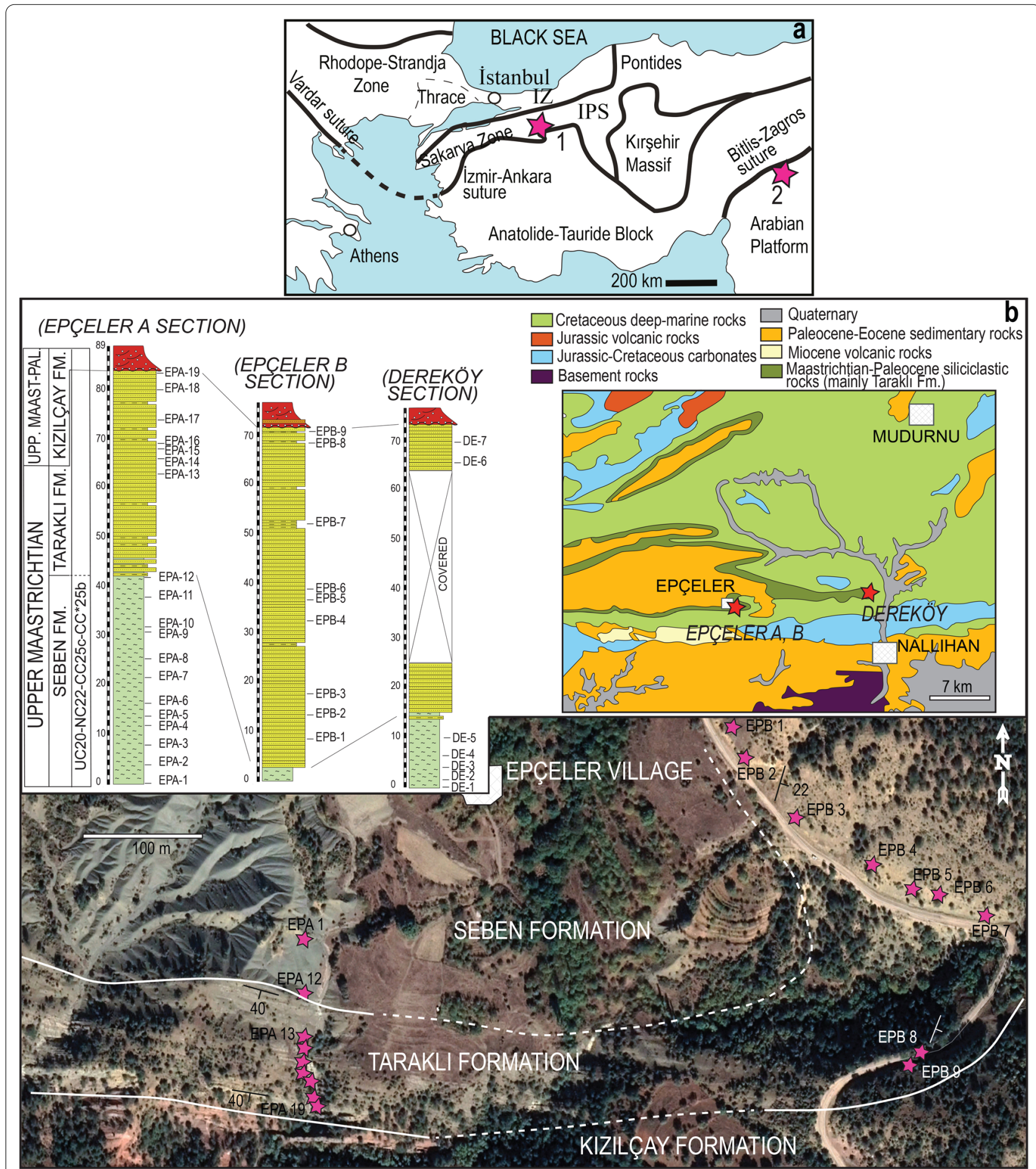

Fig. 1 a Tectonic map of the northeastern Mediterranean region showing the major sutures and continental blocks and the location of the study areas in the Central Sakarya Basin (1) and Arabian Platform margin (2) (map simplified from Okay \& Tüysüz, 1999). b Geological map of the Epçeler, Nallıhan region and lithostratigraphic log of the upper part of the Seben Formation and the Taraklı Formation (map simplified from MTA 2011). Sampling points in Epçeler A and B sections are shown 


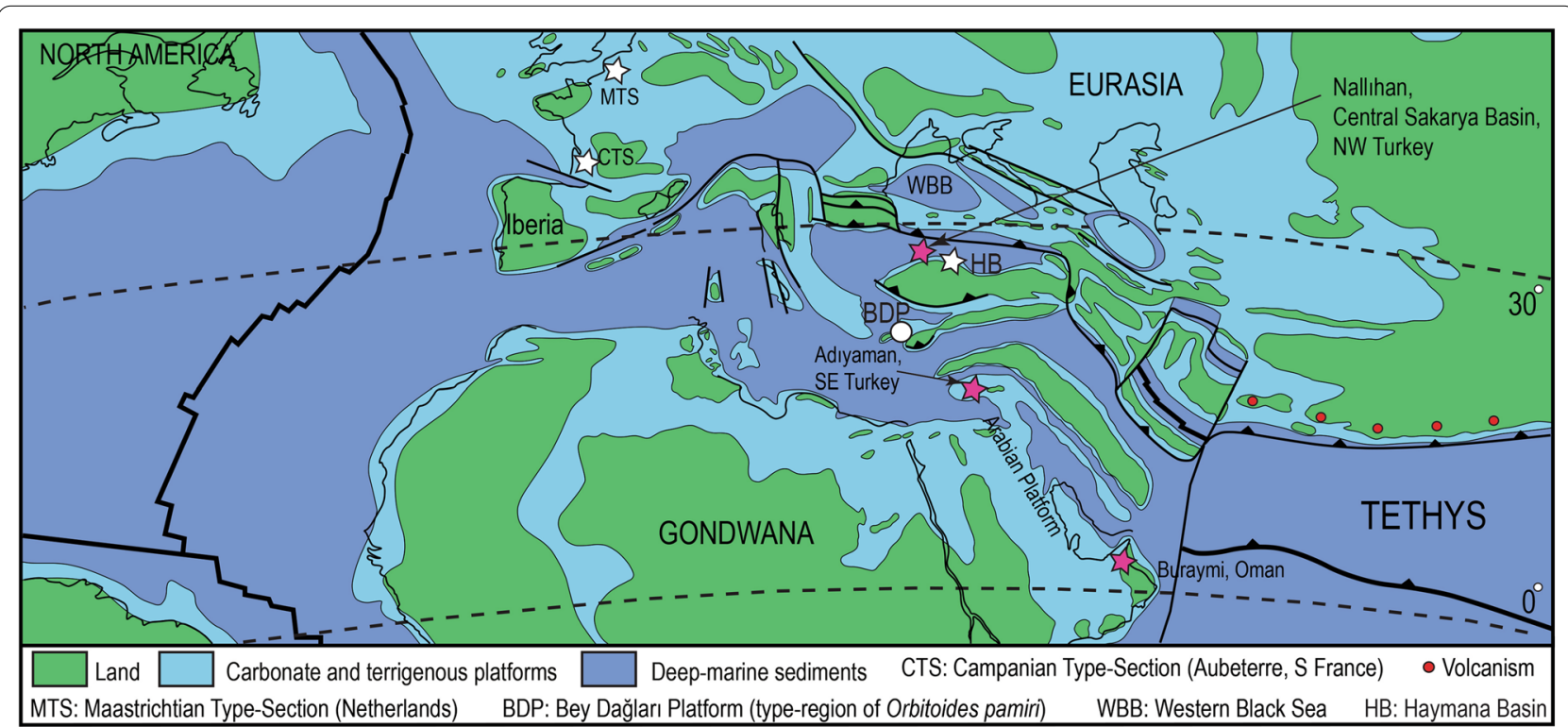

Fig. 2 Maastrichtian palaeogeography and locations of the studied sections in Turkey and Oman (shown by red) (map simplified from Barrier et al. 2018). The locations of the Campanian and Maastrichtian type sections in SW France and the Netherlands and the Haymana Basin in Central Turkey are shown

The Taraklı Formation is composed of a sandstonesiltstone succession, 100-300 m-thick, with larger foraminifera and bivalves present in some intervals. It is unconformably overlain by either continental clastic rocks of the Kızılçay Group or shallow marine carbonates of the Selvipinar Formation (Fig. 1b). The age of the Taraklı Formation was reported as Maastrichtian in the southern part of the Central Sakarya Basin (Saner, 1980), and Maastrichtian-Paleocene in the northern part (Ocakoğlu et al. 2019; Saner, 1980). Our data (including new nannofossil analyses) from the Epçeler Sections (Epçeler A and B) to the northwest of Nallihan, and from Dereköy to the north of Nallıhan, indicate a late Maastrichtian age for the Taraklı Formation. The fauna present in the Epçeler and Dereköy sections is not diverse, and is predominantly composed of Orbitoides, very rare Lepidorbitoides, Siderolites, a few broken tests of Omphalocyclus and bivalve debris (Fig. 3).

\section{Kahta, Adıyaman region (Southeastern Turkey)}

The northern margin of the Arabian Platform in Southeastern Turkey is characterised by allochthonous and pre-and/ or post-emplacement autochthonous or parautochthonous units (Perinçek, 1980; Rigo de Righi \& Cortesini, 1964; Yllmaz, 1993) (Fig. 4). The Kahta region of the Adiyaman province is one of the areas at the northern border of Arabian fold belt in which Late Cretaceous nappe emplacement and post-emplacement Late Cretaceous sedimentation are fully recorded (Meriç, 1965;
Meriç et al. 1987; Özcan, 1993, 1994) (Fig. 4). The postemplacement Terbüzek (also known as 'Antak') Formation is a thick-bedded to massive, friable and polygenetic coarse conglomerate unit with local sandstone intercalations (samples TF2 and 5). The formation is a continental to shallow marine clastic unit, which forms part of a new transgressive cycle following the Campanian- (?) early Maastrichtian nappe emplacement (Özcan, 1993, 1994). The fauna from the Terbüzek Formation consists of O. megaloformis Papp and Küpper, 1953, Lepidorbitoides bisambergensis (Jaeger, 1914), Omphalocyclus anatoliensis Özcan, 2007, Planorbulinella sp., Goupillaudina sp., and Marssonella sp., associated with rudists (Özcan, 1994, 1995, 2007; Özer, 1986). The Besni Formation is a clastic-carbonate unit, interpreted as a biohermal carbonate or beach deposit, conformably overlying the Terbüzek Formation (Meriç et al. 1987) (Fig. 4). The rapid proliferation and abundance of many larger benthic foraminiferal taxa such as Orbitoides, Siderolites, Omphalocyclus, Loftusia, Clypeorbis, Lepidorbitoides, Sirtina, Goupillaudina, together with the presence of rudists is a very characteristic feature of this formation (Özcan, 1993, 1994). Özcan (1994, 2007) assigned Orbitoides assemblages to $O$. 'medius' associated with Siderolites calcitrapoides Lamarck, 1801, Omphalocyclus anatoliensis Özcan, 2007, Sirtina cf. orbitoidiformis Brönnimann and Wirtz, 1962, and Clypeorbis aff. mamillatus (Schlumberger, 1902). An early Maastrichtian age for the Besni Formation was proposed by Özcan (1994). The overlying 


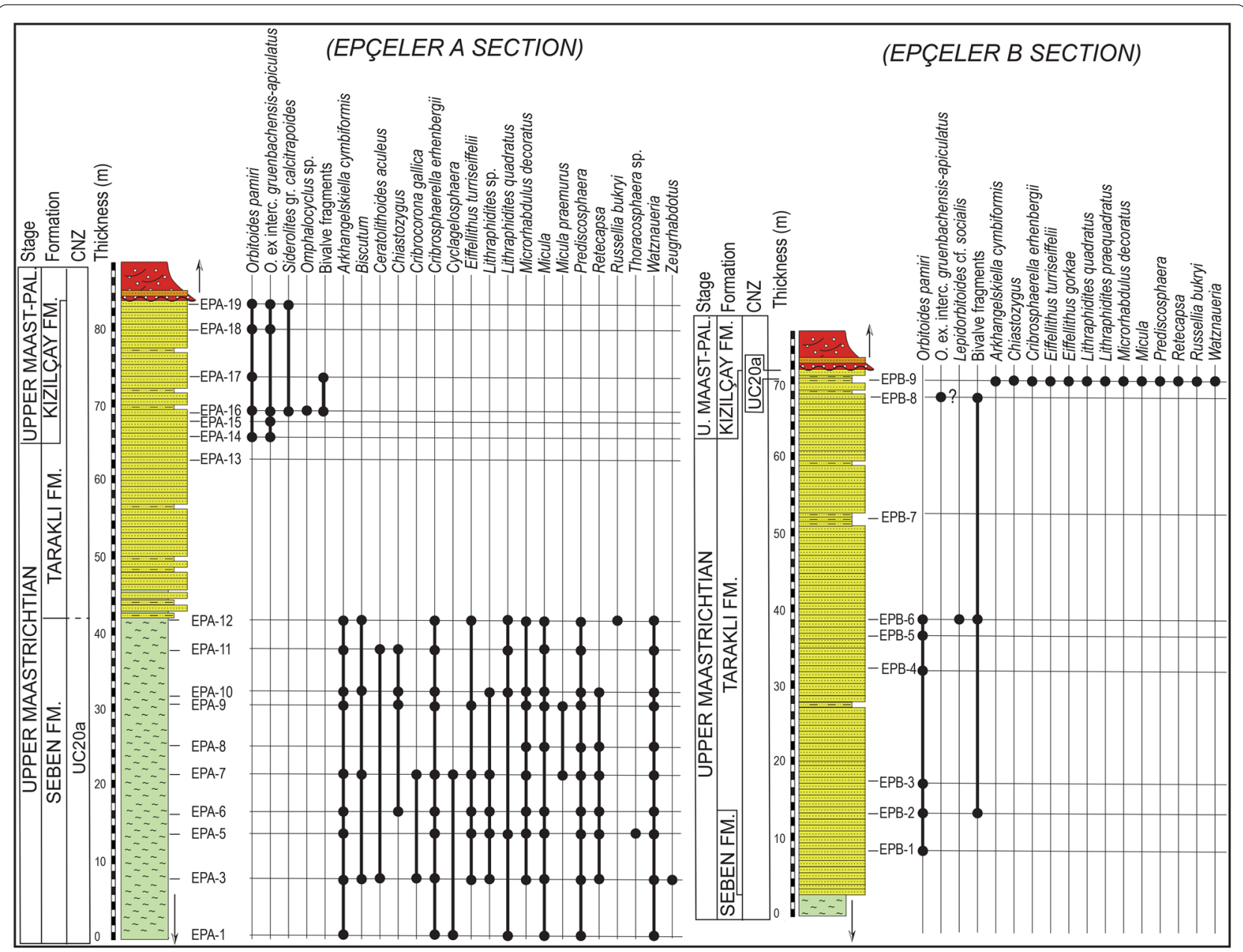

Fig. 3 Distribution of LBF, calcareous nannofossils and other fossils in the Taraklı Formation in Epçeler A and B sections

Germav Formation is predominantly composed of fine siliciclastic rocks with planktonic foraminifera. Two turbiditic beds (sample GA64 yielded an assemblage of $O$. 'megaloformis' and $L$. gr. minor-socialis associated with Siderolites calcitrapoides, Siderolites denticulatus Douvillé, 1906, Omphalocyclus. cf. macroporus (Lamarck, 1816), Pseudomphalocyclus blumenthali Meriç, 1980, S. cf. orbitoidiformis, and Loftusia spp. (Özcan, 1993, 1994). The age of the Germav Formation has been reported as early-middle/late Maastrichtian. Tertiary deposits unconformably overlie the Upper Cretaceous units and are represented by the continental red beds of the Gercüş Formation and carbonates of the Midyat Group.

\section{Haymana Basin, Central Turkey}

The Haymana Basin is a thick clastic depocentre of Late Cretaceous to Eocene age in central Anatolia (Özcan et al. 2020). The Beyobasi Formation, the uppermost stratigraphic unit of the Cretaceous sequence, is a shallow marine-mixed carbonate-siliciclastic deposit consisting of siltstone-sandstone and bioclastic limestone beds. The Beyobası Formation contains O. apiculatus, O. 'medius', L. socialis, O. macroporus, Siderolites sp., Loftusia sp., Sirtina sp., Hellenocyclina sp. and Cideina sp., accompanied by Cyclolites sp., bivalves and gastropods indicating a late Maastrichtian age (Özcan \& Özkan-Altıner, 1997).

\section{Buraymi region, North Oman}

The Qahlah and Simsima Formations are the first autochthonous sediments deposited on the obducted ophiolite complex in Oman. They are characterised by an abundance of benthic foraminifera and rudists, along with corals, calcareous algae, gastropods and echinoids (Abdelghany, 2003; Béchennec et al. 1993; Kayğılı et al. 2021; Nolan et al. 1990; Roger et al. 1993; Schlüter et al. 2008; Skelton et al. 1990). A road-cut section to the northeast of Buraymi in North Oman shows an expanded section of the marine part of the Qahlah Formation 


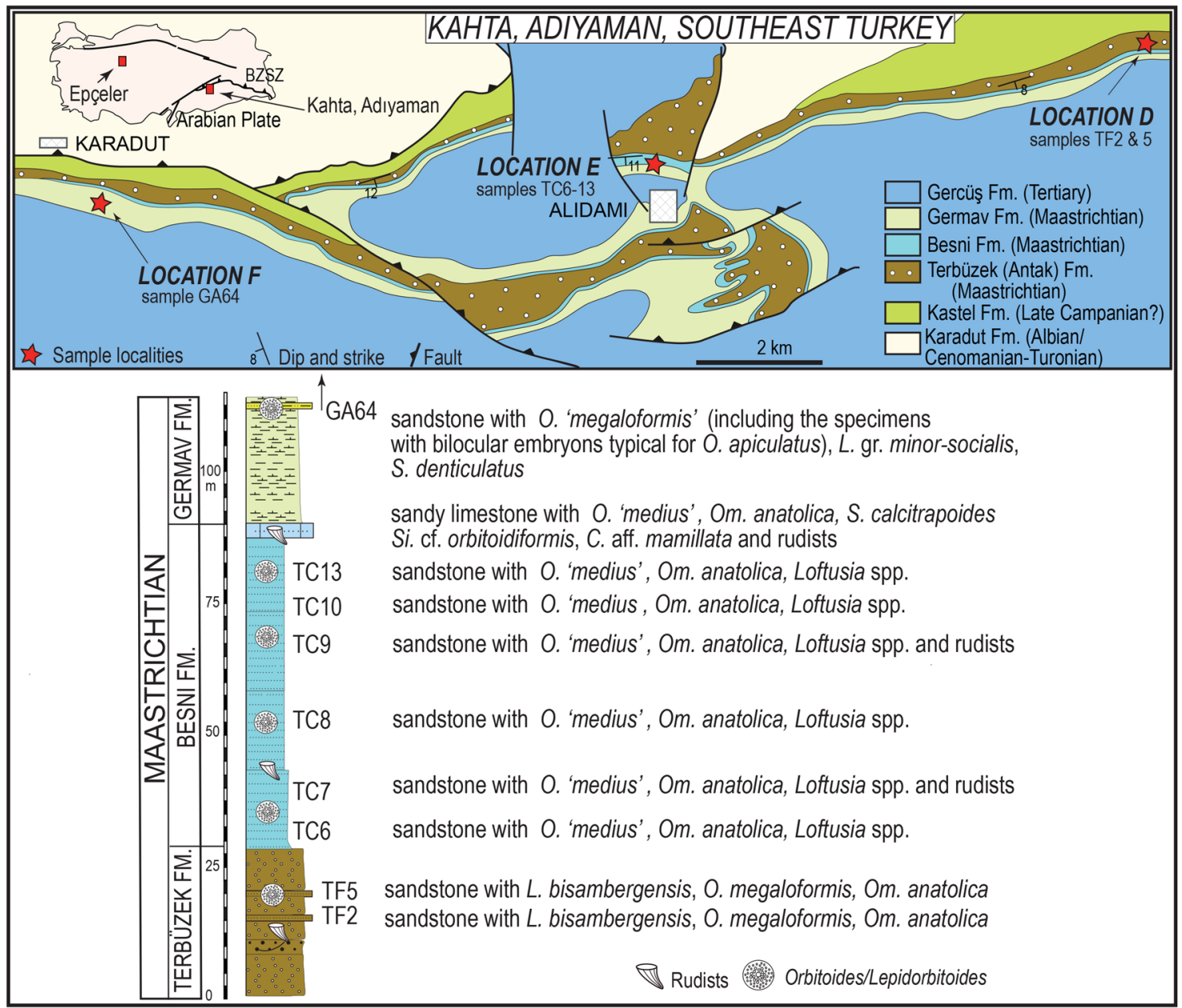

Fig. 4 Simplified geological map of the Kahta, Adıyaman region in SE Turkey (after Özcan, 1994) and a composite lithostratigraphic log of the Terbüzek, Besni and Germav Formations with positions of the samples

immediately below the Simsima Formation (Fig. 5) (Buraymi Section in Kayğılı et al. 2021). The upper Campanian Qahlah Formation here consists of massive mudstone/marl and siltstone beds with primitive Omphalocyclus (O. omanensis sp. nov. in Kayğgllı et al. 2021), O. medius and calcareous nannofossils with a typical late Campanian assemblage (zones CC22b and CC23a). The marine siliciclastic beds in the upper part of the Qahlah Formation are overlain by a paleosol horizon and a conglomerate bed with predominantly chert pebbles, with a sharp contact with the overlying Simsima Formation.

The Simsima Formation is of variable thickness (2.5$200 \mathrm{~m}$ ) and is a shallow marine bioclastic limestone. Foraminifera reported from previous studies include O. medius, O. apiculatus, O. macroporus, Pseudomphalocyclus blumenthali, L. cf. minor, Siderolites calcitrapoides, Loftusia morgani Douvillé, Sulcoperculina dickersoni (Palmer) (Abdelghany, 2003; Béchennec et al.
1993; Schlüter et al. 2008; Skelton et al. 1990). Rudists are common, with assemblages including Vaccinites, Hippurites, Durania, Biradiolites, Dictyoptychus, Torreites, Vautrinia, Bournonia, Pseudopolyconites, and Sabinia (Skelton et al. 1990). In the Buraymi region, the Simsima Formation begins with a succession of nodular, resistant calcarenitic beds, 9-m-thick, with clay partings (Fig. 5). This part is highly fossiliferous, dominated by $O$. gensacicus (Leymerie, 1851), Lepidorbitoides ex. interc. socialis (Leymerie, 1851)-minor (Schlumberger, 1902), Sirtina orbitoidiformis Brönnimann and Wirtz, 1962, Clypeorbis cf. mamillatus (Schlumberger, 1902), Ilgazina unilateralis Erdoğan, 1995, Siderolites sp., O. cf. macroporus, Pseudorotalia sp., Rotalispira sp., Fallotia sp., Planorbulina sp., Fissoelphidium sp., algae, miliolids, gastropods and agglutinated foraminifera (Özcan et al. 2021). The age of the studied populations is, thus, safely constrained to the Maastrichtian, most likely to the late (not 


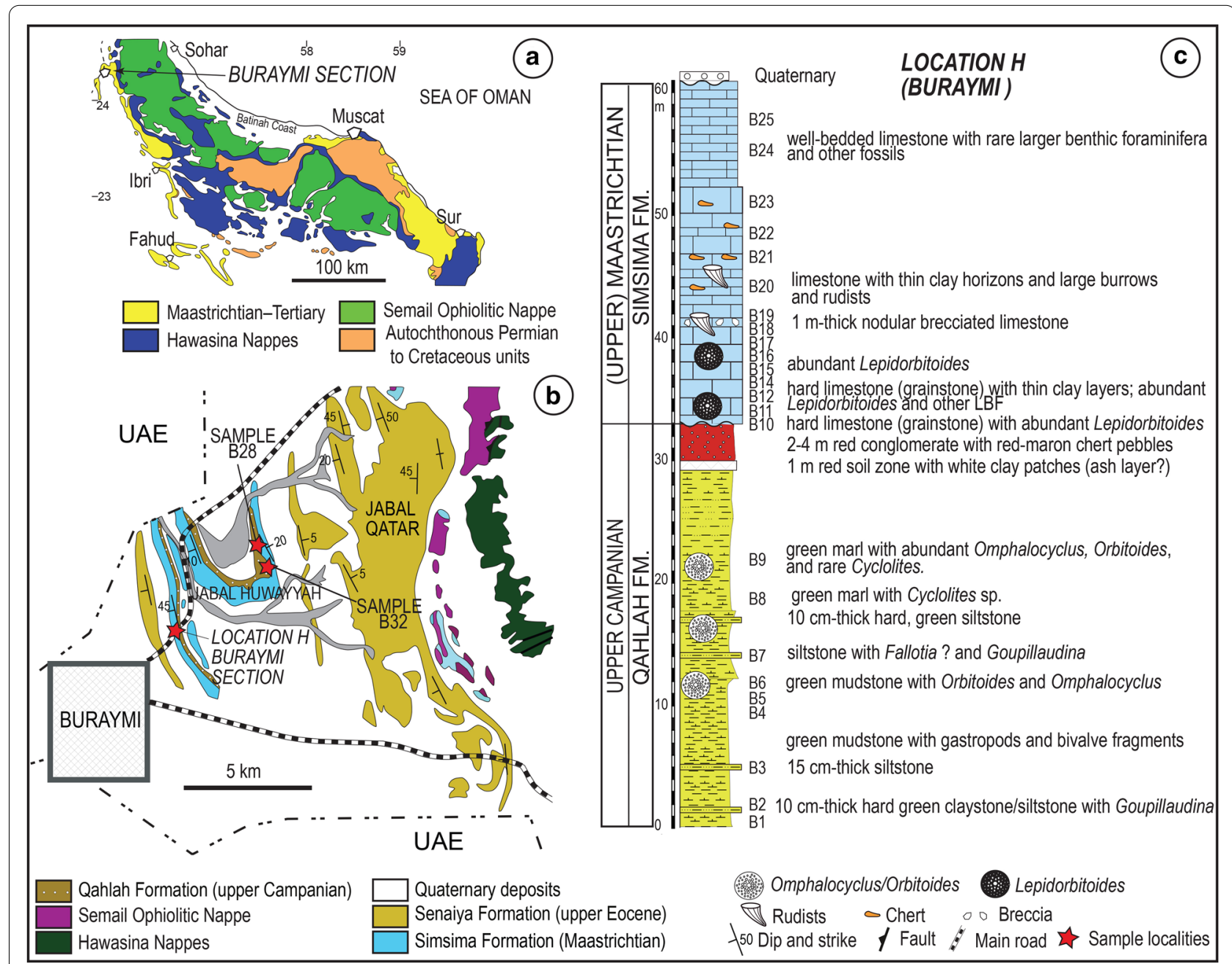

Fig. 5 a Simplified geological map of the Oman Mountains (after Glennie et al., 1974). b Geological map of the Buraymi region and location of the Buraymi Section and samples 28 and 32 (map simplified from Métour et al. 1992). c Lithostratigraphic columnar section of the Qahlah and the Simsima formations

latest) Maastrichtian by the co-occurrence of the primitive developmental stage of $L$. socialis and O. gensacicus, a 'late Maastrichtian' key species in Europe (Caus et al. 1996; Eggink \& Baumfalk, 1983; Özcan \& Özkan-Altıner, 1997). O. gensacicus, recorded for the first time from the Simsima Formation in Oman, is accepted as the youngest representative of the genus and thus, its presence in the Simsima Formation unequivocally suggests a late Maastrichtian age.

\section{Materials and methods}

Samples were collected at three localities (Localities A-C) in the southeastern part of the Central Sakarya Basin, near Nallihan (province of Ankara), and from three localities at the Arabian Platform margin (Localities D-F) in SE Turkey (Figs. 1 and 4). Samples from the Haymana Basin (Locality G) in Central Turkey, and Buraymi region (Locality H) in north Oman (Fig. 5), are also incorporated to this study.

Locality A (Epçeler A Section, Central Sakarya Basin): 19 samples were collected to the south of Epçeler village near Nallıhan, Ankara province (Fig. 1b). Samples 1-12 are from the massive marly beds of the Seben Formation below the sandstones of the Taraklı Formation, and samples 13-19 (sample 13: $40^{\circ} 14^{\prime} 6.64^{\prime \prime} \mathrm{N}, 31^{\circ} 5^{\prime}$ 39.19" E; sample 19: $40^{\circ} 14^{\prime} 5.10^{\prime \prime} \mathrm{N}, 31^{\circ} 5^{\prime} 39.72^{\prime \prime} \mathrm{E}$ ) come from the middle and upper part of sandstone succession of the Taraklı Formation. The Taraklı Formation is unconformably overlain by coarse red beds of the Kızılçay Formation.

Locality B (Epçeler B Section, Central Sakarya Basin): Samples EPB 1-9 were taken from the Taraklı 
Formation near Epçeler village, approximately $700 \mathrm{~m}$ east of Locality A, to the southeast of Epçeler village (sample 1: $40^{\circ} 14^{\prime} 15.01^{\prime \prime} \mathrm{N}, 31^{\circ} 5^{\prime} 56.51^{\prime \prime} \mathrm{E} ; 40^{\circ} 14^{\prime} 6.19^{\prime \prime}$ $\mathrm{N}$, sample 9: $\left.40^{\circ} 14^{\prime} 6.19^{\prime \prime} \mathrm{N}, 31^{\circ} 6^{\prime} 1.83^{\prime \prime} \mathrm{E}\right)$.

Locality C (Dereköy Section, Central Sakarya Basin): Samples DE 6 and 7 were taken from the upper part of the Taraklı Formation near Dereköy village to the northwest of Nallihan, Ankara province (sample 6: $40^{\circ}$ $15^{\prime} 51.45^{\prime \prime} \mathrm{N}, 31^{\circ} 20^{\prime} 9.55^{\prime \prime} \mathrm{E}$, sample $7: 40^{\circ} 15^{\prime} 51.71^{\prime \prime} \mathrm{N}$, $31^{\circ} 20^{\prime} 9.43^{\prime \prime} \mathrm{E}$ ).

Locality D (SE Turkey). Samples TF2 and TF5 come from the middle part of the Terbüzek Formation to the west of Alidamı, Kahta, Adiyaman province $\left(37^{\circ} 55^{\prime}\right.$ $38.12^{\prime \prime} \mathrm{N}, 38^{\circ} 54^{\prime} 8.70^{\prime \prime} \mathrm{E}$ and $37^{\circ} 55^{\prime} 35.54^{\prime \prime} \mathrm{N}, 38^{\circ} 54^{\prime}$ 7.74" E) (Özcan, 1994).

Locality E (SE Turkey). Samples TC6-10 and 13 were collected from the Besni Formation to the north of Alidamı, Kahta, Adiyaman province $\left(37^{\circ} 56^{\prime} 6.26^{\prime \prime} \mathrm{N}\right.$, $38^{\circ} 58^{\prime} 16.36^{\prime \prime}$ E) (Özcan, 1994).

Locality F (SE Turkey). Sample GA64 was taken from a turbiditic bed of the Germav Formation to the southeast of Karadut, Kahta, Adiyaman province ( $37^{\circ} 55^{\prime}$ $\left.15.99^{\prime \prime} \mathrm{N}, 38^{\circ} 47^{\prime} 46.44^{\prime \prime} \mathrm{E}\right)$ (Özcan, 1994).

Locality G (Haymana Basin, Central Turkey). Samples DEG16-20B were collected just below the CretaceousCenozoic boundary near the village of Sarıdeğirmen $\left(39^{\circ} 30^{\prime} 37.21^{\prime \prime} \mathrm{N} ; 32^{\circ} 26^{\prime} 53.24^{\prime \prime}\right.$ E) (Özcan \& ÖzkanAltıner, 1997).

Locality H (Buraymi region, North Oman). The samples B6, B8 and B9 were collected from the upper part of the Campanian Qahlah Formation near Buraymi $\left(24^{\circ}\right.$ $16^{\prime} 48.57^{\prime \prime} \mathrm{N} ; 55^{\circ} 49^{\prime} 26.96^{\prime \prime} \mathrm{E} ; 24^{\circ} 16^{\prime} 49.84^{\prime \prime} \mathrm{N} ; 55^{\circ} 49^{\prime}$ $24.68^{\prime \prime}$ E). A detailed description of the Buraymi section is given by Kayğılı et al. (2021).

The material from the Taraklı Formation consists of 359 isolated Orbitoides specimens studied in equatorial sections and about 50 specimens studied in axial sections, and a single Lepidorbitoides specimen, investigated through its equatorial section, supplemented by random thin sections. The material from the Terbüzek and Besni Formations consists of 261 Orbitoides specimens studied in their equatorial sections and 14 specimens studied in axial sections. Equatorial, axial and tangential sections, essential for taxonomy, require the grinding of the isolated test on preferred orientations by a fine grinding paper. The measurements and counts used in the morphometry of these taxa are shown in Tables 1 and 2. All specimens are deposited in the palaeontological collections of the Geological Engineering Department of İstanbul Technical University and prefixed EO/. For calcareous nannofossils, eleven samples from Epçeler A Section and one sample from Epçeler B Section, and five from Dereköy Section were collected.
They were prepared as simple smear slides following standard procedures (Bown \& Young, 1998) and analysed through a polarised light microscope at $\times 1250$ magnification.

\section{Species concept and evolutionary trends in Orbitoides}

The definition of species in palaeontology is fraught with difficulty. On one hand, we may seek to attempt to determine that a fossil species has equivalent meaning to that of a biological species-a grouping of organisms that can interbreed and are reproductively isolated from other groups. Our recognition of species may attempt to allude to this unknowable goal. More practically, we may try to define species as distinct forms within the process of evolution, capturing the progressive stages of the evolution of a genus or related group of genera. Very often, species are defined because they seem distinct enough to a palaeontologist to merit separation. This can be very subjective, especially if the evolutionary context of the new species being described is not well understood.

The concept of species definition in larger benthic foraminifera (LBF) is a case in point. Differences in the complex internal structure of many LBF are the basis for species definition, with external morphology often a secondary consideration, as it is often viewed as being controlled by localised environmental factors. In several LBF groups, including Orbitoides, two approaches to species definition have arisen. The first is a typological approach, following long palaeontological tradition. A grouping of the size and shape of internal features, and perhaps external features, collectively define a species with reference to type specimens. This method has been described as "the intuitive appraisal of differences recognised by the specialist on the basis of his 'experience' " (Drooger, 1993), in other words, the entire process of empirical pattern recognition (Less \& Kovacs, 2009). The second is a morphometric approach, where a statistical analysis of morphological characters (such as diameter of the embryon, and size and number of peri-embryonic chambers) in an adequate number of samples from successive populations can be used to define the evolutionary stages of each character to form a bioseries. Both methods have advantages and disadvantages (Less \& Kovacs, 2009; Pignatti, 1998). A potential pitfall of morphometric methods is that they consider a population of generally similar forms to be a single species, and thus, representative of the range within that species. This means that co-existing parallel lineages can be overlooked.

Since the first description of Orbitoides by d'Orbigny, many species have been described based on various criteria (see van Gorsel, 1978 for a historical account). Classification follows either typological (based on overall test 
Table 1 Morphometric data of Orbitoides from the Taraklı, Terbüzek, Besni and Germav Formations

\begin{tabular}{|c|c|c|c|c|c|c|}
\hline \multirow[t]{2}{*}{ Sample } & \multirow[t]{2}{*}{$\mathrm{N}$} & \multicolumn{2}{|l|}{$\mathrm{Li}+\mathrm{li}$} & \multicolumn{2}{|l|}{$E$} & \multirow[t]{2}{*}{ Species } \\
\hline & & Range ( $\mu \mathrm{m})$ & Mean \pm s.e $(\mu m)$ & Range & Mean & \\
\hline EPA14 & 43 & 650.0-1310.0 & $919.50 \pm 22.2$ & $8-20$ & 13.10 & $\begin{array}{l}\text { O. ex. interc. } \\
\text { gruenbachensis- }\end{array}$ \\
\hline EPA15 & 38 & $530.0-1300.0$ & $886.90 \pm 31.2$ & $8-17$ & 13.00 & \\
\hline EPA16 & 25 & $645.0-1400.0$ & $935.00 \pm 38.5$ & $8-18$ & 13.33 & \\
\hline EPA18 & 9 & $675.0-1240.0$ & $920.00 \pm 54.5$ & $10-16$ & 13.56 & \\
\hline EPA19 & 13 & $735.0-1320.0$ & $895.77 \pm 44.5$ & $8-17$ & 13.40 & \\
\hline DE 6 & 24 & $540.0-1350.0$ & $862.92 \pm 39.7$ & $9-18$ & 14.30 & \\
\hline DE 7 & 37 & $560.0-1310.0$ & $854.86 \pm 29.5$ & $10-19$ & 14.00 & \\
\hline DEG16-20 & 34 & $665.0-1380.0$ & $1023.4 \pm 29.7$ & $11-20$ & 14.94 & O. apiculatus \\
\hline EPB1 & 7 & $415.0-655.0$ & $516.43 \pm 29.3$ & $3-5$ & 4.00 & O.pamiri \\
\hline EPB2 & 21 & $280.0-580.0$ & $452.25 \pm 20.1$ & $3-5$ & 3.95 & \\
\hline EPB3 & 42 & $325.0-600.0$ & $422.38 \pm 10.2$ & $3-5$ & 4.02 & \\
\hline EPB4 & 24 & $225.0-615.0$ & $424.38 \pm 18.4$ & $3-6$ & 4.04 & \\
\hline EPB5 & 17 & $300.0-650.0$ & $421.18 \pm 20.8$ & $4-6$ & 4.13 & \\
\hline EPB6 & 39 & $290.0-730.0$ & $456.92 \pm 17.9$ & $4-5$ & 4.06 & \\
\hline EPA14 & 1 & & 330.0 & & & \\
\hline EPA16 & 1 & & 385.0 & & & \\
\hline EPA17 & 2 & $330.0-600$ & 465.0 & $4-4$ & 4.0 & \\
\hline EPA18 & 10 & $315.0-575.0$ & $454.5 \pm 21.4$ & $4-4$ & 4.0 & \\
\hline EPA19 & 5 & $350.0-530.0$ & $438.0 \pm 31.7$ & $4-4$ & 4.0 & \\
\hline DE 7 & 1 & & 475.0 & & & \\
\hline TF2 & 45 & $415.0-1155.0$ & $700.3 \pm 22.3$ & $4-15$ & 9.13 & O. megaloformis \\
\hline TF5 & 72 & $315.0-1050.0$ & $698.4 \pm 19.9$ & $4-15$ & 8.60 & \\
\hline B6 & 11 & $260.0-690.0$ & $440.5 \pm 34.28$ & $4-5$ & 4.20 & O. medius \\
\hline B8 & 11 & $260.0-600.0$ & $450.0 \pm 28.80$ & $4-5$ & 4.36 & \\
\hline B9 & 19 & $260.0-690.0$ & $440.5 \pm 34.28$ & $4-5$ & 4.20 & \\
\hline TC6 & 33 & $360.0-860.0$ & $554.4 \pm 21.8$ & $4-9$ & 5.23 & O. 'medius' \\
\hline $\mathrm{TC7}$ & 27 & $345.0-785.0$ & $536.5 \pm 22.9$ & $4-8$ & 5.0 & \\
\hline TC8 & 39 & $360.0-950.0$ & $525.3 \pm 19.1$ & $4-8$ & 5.21 & \\
\hline TC9 & 6 & $430.0-500.0$ & $461.7 \pm 10.6$ & $4-5$ & 4.40 & \\
\hline $\mathrm{TC} 10$ & 11 & $395.0-780.0$ & $523.7 \pm 30.8$ & $4-6$ & 4.63 & \\
\hline TC13 & 28 & $365.0-815.0$ & $541.1 \pm 23.8$ & $4-9$ & 5.41 & \\
\hline DEG16-20 & 2 & $365.0-555.0$ & 460.0 & & 5.0 & \\
\hline B28 & 2 & $450.0-505.0$ & $477.5 \pm 19.45$ & 4 & 4.0 & \\
\hline B32 & 2 & $510.0-545.0$ & $527.5 \pm 12.37$ & $4-7(?)$ & 5.5 & \\
\hline
\end{tabular}

Morphometric data of O. medius (Samples B6, 8 and 9) from the upper Campanian of Oman and O. 'medius' from the upper Maastrichtian of Beyobası Formation (sample 16-20) are given for comparison purposes. N denotes the number of specimens. Li + li: size of the embryon, E: total number of epi-embryonic chamberlets (see Fig. 6)

features; shape of the test, features of piles and lateral layers, type of embryonic apparatus) or morphometric species concepts. The latter approach, based on the study of the embryonic apparatus and the surrounding nepionic chamberlets, results in a single evolutionary series consisting of quantitatively defined 'chronospecies' the boundaries of which are arbitrary (Figs. 6, 7). According to this approach, all specimens from a population are assigned to a single species.
The morphological changes recorded in the equatorial layer of Late Cretaceous orbitoidal foraminifera (e.g. Orbitoides, Lepidorbitoides) are expressed by the concept of nepionic-embryonic acceleration (Drooger, 1983, 1993; van Hinte, 1966b, 1976). This is based on a progression resulting in fewer steps of chambers until the individuals attain the ontogenetic stage of cyclical development, and a tendency for an increase in the size of the embryon. In this approach to species definition, other 
Table 2 Measurements of Orbitoides test diameter (TD) and thickness (TT), thickness of equatorial layer in nepionic stage (EL1) and near the periphery of the test (EL2) and diameter of stolons near the periphery of test (ST)

\begin{tabular}{|c|c|c|c|c|c|c|c|}
\hline Sa & $N$ & $\begin{array}{l}\text { TD } \\
\text { Range and mean (mm) }\end{array}$ & $\begin{array}{l}\mathrm{TT} \\
\text { Range and mean (mm) }\end{array}$ & $\begin{array}{l}\text { EL1 } \\
\text { Range and mean }(\mu \mathrm{m})\end{array}$ & $\begin{array}{l}\text { EL2 } \\
\text { Range and mean }(\mu \mathrm{m})\end{array}$ & $\begin{array}{l}\text { ST } \\
(\mu \mathrm{m})\end{array}$ & Species \\
\hline EPA14 & 8 & $3.25-6.84 .47$ & $0.65-1.951 .17$ & $95.0-165.0135 .0$ & $105.0-245.0160 .0$ & $25-50$ & \multirow{5}{*}{$\begin{array}{l}\text { O. ex. interc. } \\
\text { Gruenbachensis- } \\
\text { apiculatus }\end{array}$} \\
\hline EPA15 & 9 & $4.05-5.95 .10$ & $1.02-1.821 .41$ & $75.0-150.0121 .6$ & $125.0-210.0157 .2$ & $35-40$ & \\
\hline EPA16 & 1 & 6.0 & 2.01 & 120.0 & 155.0 & & \\
\hline EPA19 & 1 & 2.5 & 0.78 & 110.0 & 115.0 & & \\
\hline DE 7 & 2 & $2.95-4.453 .7$ & 0.96 & $110.0-130.0120 .0$ & $125.0-140.0132 .5$ & & \\
\hline EPB1 & 1 & 6.17 & 0.67 & 140.0 & 440.0 & & \multirow[t]{6}{*}{ O.pamiri } \\
\hline EPB2 & 1 & 5.0 & 1.0 & 105.0 & 220.0 & & \\
\hline EPB3 & 1 & 5.63 & 1.11 & 140.0 & 325.0 & & \\
\hline EPB4 & 1 & 6.07 & 1.1 & 110.0 & 275.0 & & \\
\hline EPB5 & 14 & $2.91-5.74 .26$ & $0.45-0.920 .69$ & $85.0-150.0116 .8$ & $170.0-325.0238 .1$ & $35-40$ & \\
\hline EPB6 & 1 & 5.02 & 0.87 & 150.0 & 460.0 & & \\
\hline $\mathrm{BC} 6$ & 26 & $1.9-5.43 .98$ & $0.75-2.11 .42$ & $85.0-140.0113 .8$ & 130.0-205.0 157.1 & $25-30$ & O. medius \\
\hline TC7 & 8 & $3.25-4.413 .88$ & $1.43-1.971 .72$ & $140.0-190.0160 .0$ & $220.0-285.0252 .5$ & $30-35$ & O. 'medius' \\
\hline TC13 & 6 & $2.25-3.993 .3$ & $0.97-2.121 .77$ & $130.0-165.0146 .6$ & $215.0-290.0249 .1$ & $35-40$ & \\
\hline
\end{tabular}

$N$ number of the specimens

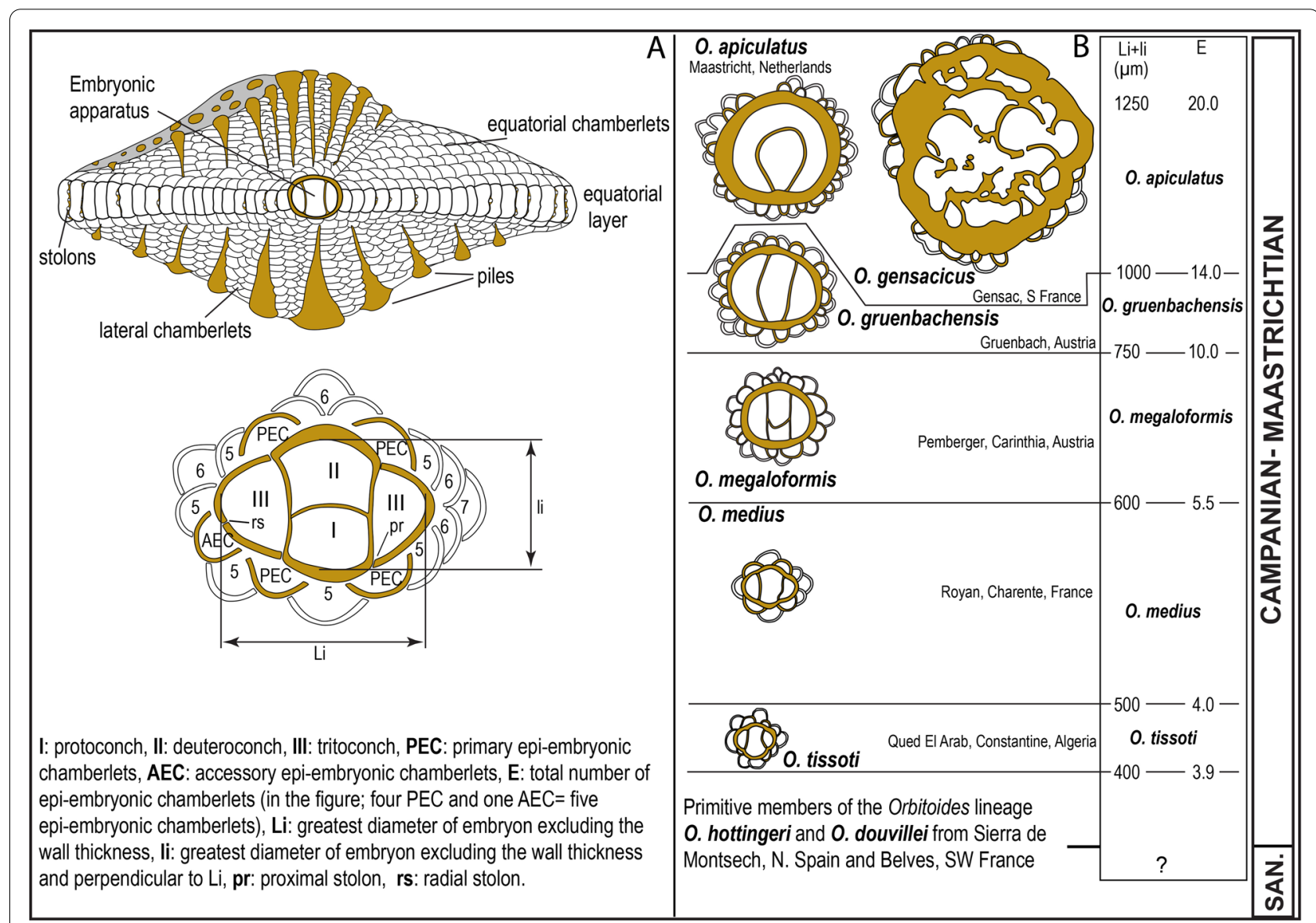

Fig. 6 a Morphological elements of genus Orbitoides; block diagram of the test and nomenclature for embryonic-nepionic stage of the megalospheric generations. b Schematic morphological changes in Orbitoides and their stratigraphic relationship. Species parameters and limits are shown. Nomenclature is after van Hinte (1965) and Baumfalk (1986), and species limits after van Hinte (1976) 


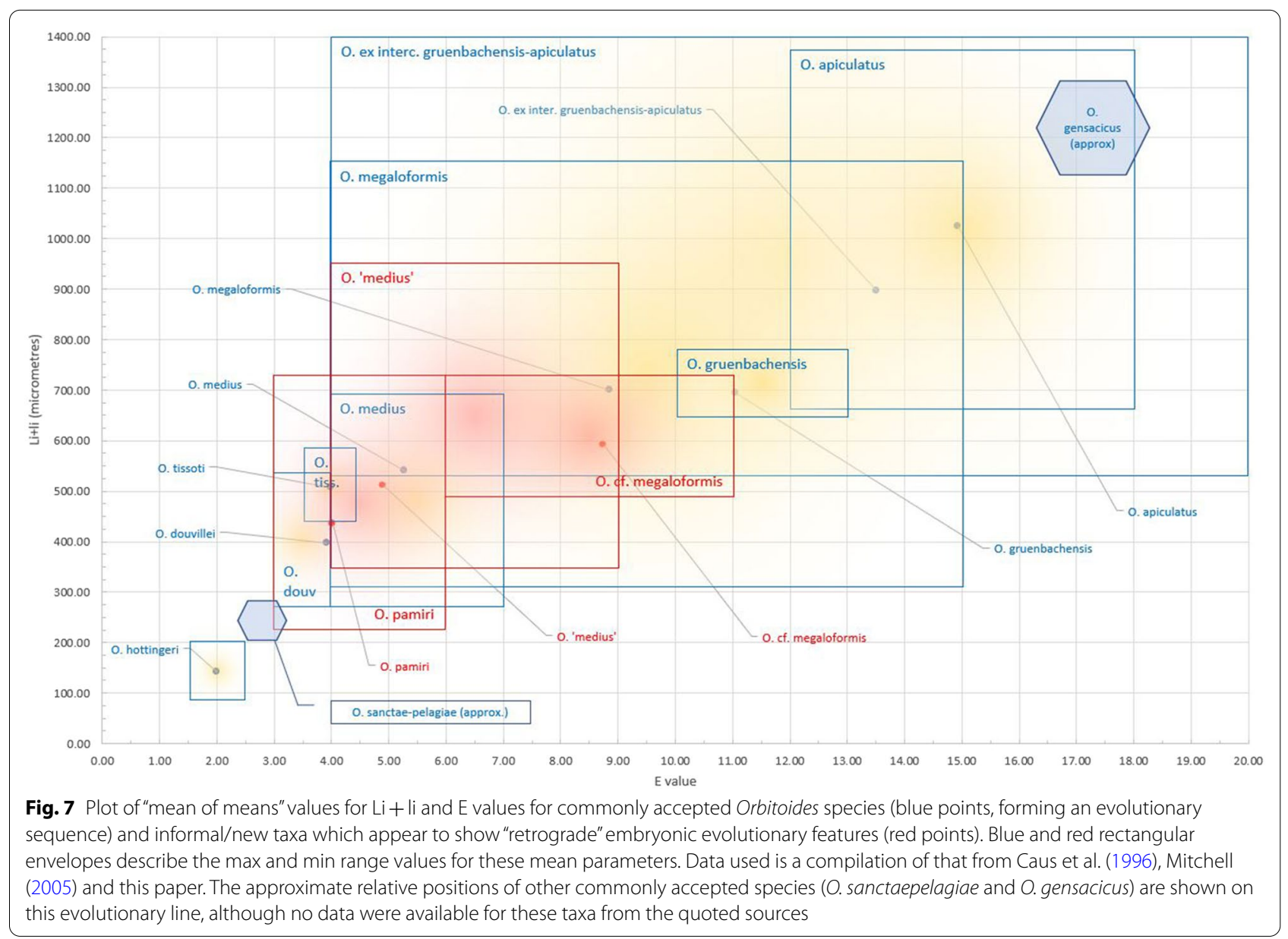

test features, specifically shape of the test and piles, are interpreted as environmentally controlled and not used in species characterisation (van Gorsel, 1978). In contrast, Neumann $(1972,1987)$ concluded that primitive species of the genus (e.g. O. dordoniensis) actually belong to Planorbulina or Planorbulinella, and considered O. tissoti, O. medius and O. apiculatus as the only valid species of Orbitoides. Research on Orbitoides populations from the (upper) Campanian type section at Aubeterre (SW France) (Figs. 2, 8a), (upper) Maastrichtian type sections at ENCI quarry (St. Pietersberg, Netherland) (Figs. 2, 8b) and adjacent regions form the backbone of the morphometric studies and phylogenetic interpretations (Baumfalk, 1986; Baumfalk \& Willemsen, 1986; Caus et al. 1996; Eggink \& Baumfalk, 1983; van Hinte, 1966b) (Figs. 6, 7).

Key biometric features being considered as definitive include embryonic apparatus size (expressed as $\mathrm{Li}+\mathrm{li}$ ) and number of epi-embryonic chamberlets (EPC) (expressed by $\mathrm{E}$, total number of primary and accessory EPC). Size and number of EPC has typically been assumed to increase with time, providing biostratigraphic utility through the definition of a series of biozones (Caus et al. 1996). Whilst this lineage is not perfectly calibrated to the standard stages of the Late Cretaceous (and bearing in mind calibration issues caused by the definition of the base Maastrichtian GSSP (Odin \& Lamaurelle, 2001)), O. gruenbachensis Papp, O. apiculatus, and O. gensacicus, with relatively large apparatus and many epi-embryonic chamberlets (Fig. 7) are typically considered as Maastrichtian (Caus et al. 1996). It is important to note that this lineage has been defined based mostly on material from the Campanian and Maastrichtian stratotypes and allied sections in Western Europe. Can the concept of a simple single lineage be challenged by data from other Tethyan margins where Orbitoides proliferated (e.g. Turkey, Arabia) and from the Caribbean?

Previous studies have considered that $O$. medius and $O$. megaloformis are typical late Campanian species and the evolution from O. medius to O. megaloformis is not gradual but involves a relatively short interval of transition in which former is replaced by the latter (Baumfalk, 1986). Similarly, the evolution of O. apiculatus within the Maastrichtian type section involves a general increase in the embryon size and number of epi-embryonic chamberlets 


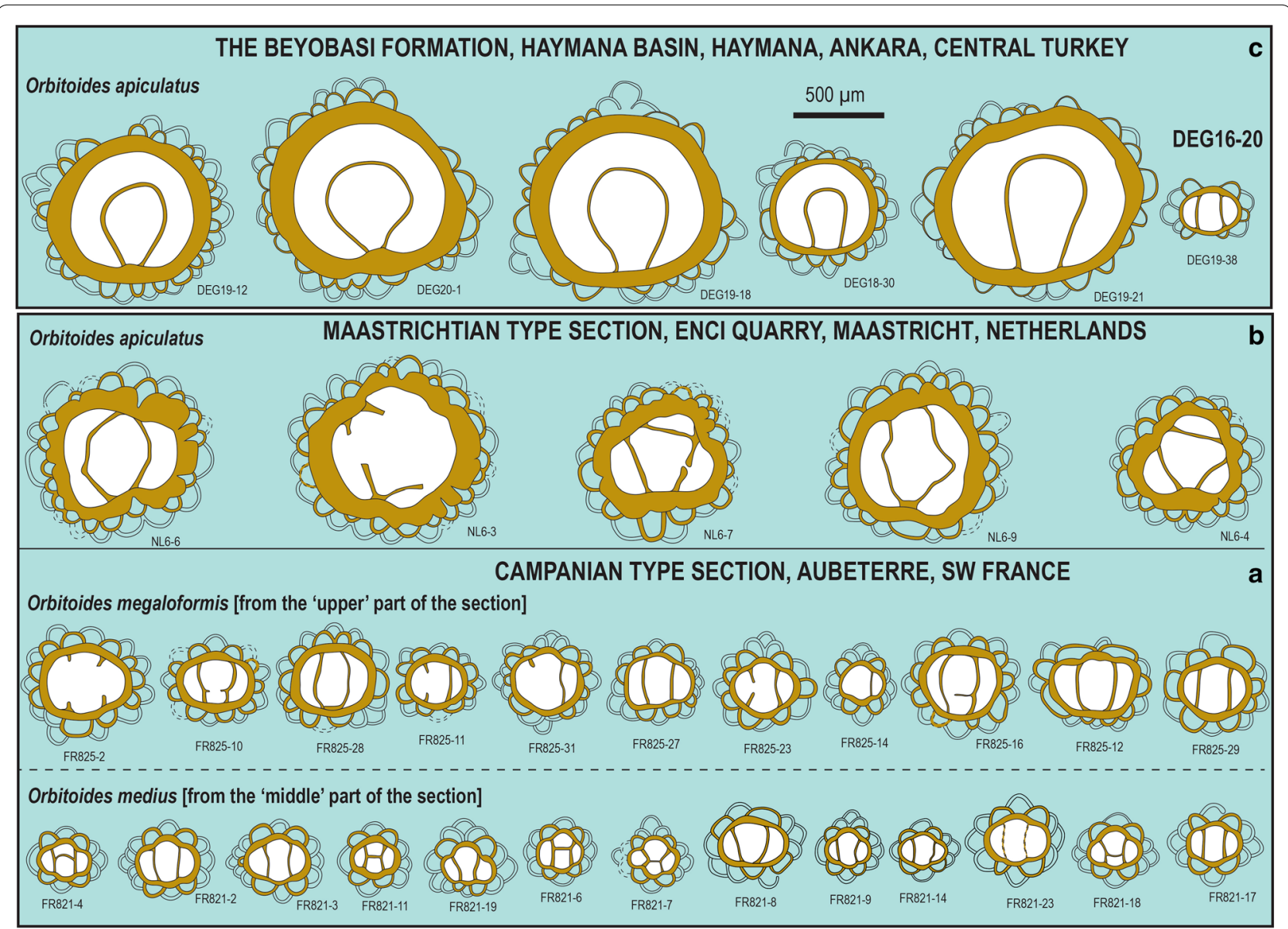

Fig. 8 Line drawings of the embryonic-nepionic stages of Orbitoides from the Campanian (a) and Maastrichtian type sections (redrawn from van Hinte 1966b) (b) and from the upper Maastrichtian of the Haymana Basin (redrawn from Özcan and Özkan-Altıner 1997) (c). A stratigraphic column of the Campanian type section and positions of samples (abbreviated as FR) are given in van Hinte (1966b). Note the occurrence of specimens with 'O. medius' type embryonic apparatus associating with O. apiculatus in the upper Maastrichtian of the Haymana Basin (Central Turkey)

although more 'advanced' populations were recorded from the debris layers over the hardgrounds present, and the intervals between the hardgrounds contain specimens with rather smaller embryons, a phenomenon ascribed to the specific environmental conditions (Baumfalk \& Willemsen, 1986).

O. gensacicus with a very large embryon, which is composed of a great number of embryonic chambers, was suggested to be a direct descendent of $O$. apiculatus stock in the late Maastrichtian (Eggink \& Baumfalk, 1983). Thus, in spite of the uncertainties in the definition of the Campanian-Maastrichtian boundary in the shallow marine Tethyan realm, the Maastrichtian Orbitoides are characterised by large, tri-to quadrilocular (O. gruenbachensis-type), bilocular (O. apiculatus-type) and giant multilocular embryons (O. gensacicus-type).

In spite of the overall evolutionary trend in the increase of embryon size and formation of a greater number of epi-auxiliary chamberlets from the Campanian to the end of the Maastrichtian (Fig. 7), the occurrence of Orbitoides specimens consisting of small embryons with only a few epi-embryonic chamberlets has been frequently been reported associated with the phylogenetically advanced species such as O. gruenbachensis, O. apiculatus and $O$. gensacicus during the Maastrichtian (Baumfalk, 1986; Eggink \& Baumfalk, 1983; Meriç, 1965; Özcan \& ÖzkanAltıner, 1997, 1999; Özer et al. 2009). These specimens were either assigned to $O$. 'medius' as a separate species or were considered a part of the population that receives the species name based on morphometry. Meriç (1965) and Özcan (1994) thus reported O. medius from the Maastrichtian sequence in the Arabian Platform margin. Baumfalk (1986) has pointed out that in a purely typological sense specimens with $O$. medius-type embryons may also be found in $O$. apiculatus populations at the Maastrichtian stratotype.

The upper Maastrichtian beds, immediately below the Maastrichtian-Paleocene boundary in the Haymana 
Basin (Central Turkey), yield Orbitoides with predominantly large bilocular embryons, but also rare small tri- to quadrilocular embryons (Özcan \& Özkan-Altıner, 1997, 1999) (Figs. 2, 8c). Similarly, O. 'medius' was reported as co-occurring with $O$. apiculatus and O. gensacicus in upper Maastrichtian deposits from the Gensac-St. Marcet region in Southern France (Eggink \& Baumfalk, 1983). Furthermore, Meriç (1974) reported some flat to biconcave Orbitoides specimens from the upper Maastrichtian of the Taurus Mountains (SW Turkey) and assigned them to $O$. apiculatus pamiri $\mathrm{n}$. ssp., assuming a relationship to $O$. apiculatus. These specimens have small tri- to quadrilocular embryons and their embryonic parameters are within the limits of O. medius (Fig. 7). The tests of these specimens, however, are quite different from the biconvex test of $O$. medius, and the number of lateral chamberlet layers in this subspecies is much less than in O. medius.

\section{Results \\ Calcareous nannofossils and age of the Taraklı Formation in the Nallıhan region}

Calcareous nannofossils were studied from the Taraklı Formation to provide independent biostratigraphic calibration of age. Samples from the Epçeler A and B sections contain calcareous nannofossil assemblages characterised by low abundance and poorly preserved forms (Fig. 9). However, it was possible to recognise a certain number of taxa occurring in reasonable numbers. The most abundant genus is Micula, mainly represented by Micula staurophora (Gardet) Stradner, with minor occurrences of Micula concava (Stradner) Verbeek and Micula swastica Stradner and Steinmetz (gathered under Micula spp.) and very rare specimens of Micula praemurus (Bukry) Stradner and Steinmetz. The other well-represented genus is Watznaueria, including Watznaueria barnesiae (Black) Perch-Nielsen and subordinately Watznaueria fossacinta (Black) Bown. Another component of the assemblages is the genus Prediscosphaera, well represented by Prediscosphaera cretacea (Arkhangelsky) Gartner and in minor amounts by Prediscosphaera ponticula (Bukry) Perch-Nielsen. Lithraphidites occurs with the presence of the marker species Lithraphidites quadratus Bramlette and Martini and Lithraphidites praequadratus Roth.
Arkhangelskiella cymbiformis Vekshina occurs continuously with significant numbers of medium and large specimens. Also present are Biscutum constans (Górka) Black and Biscutum ellipticum (Górka) Grün, Retecapsa angustiforata Black and Retecapsa crenulata (Bramlette and Martini) Grün. Other components are Cribrosphaerella ehrenbergii (Arkhangelsky) Deflandre, Eiffellithus turriseiffelii (Deflandre) Reinhardt, Microrhabdulus decoratus Deflandre, and in minor amounts Ceratolithoides aculeus (Stradner) Prins and Sissingh, Chiatozygus sp., Cribrocorona gallica (Stradner) Perch-Nielsen, Cyclagelosphaera sp., Russellia bukryi Risatti and Zeugrhabdotus sp. The occurrence of L. quadratus allows for the Epçeler Section to be attributed to the late Maastrichtian UC20a Zone of Burnett, 1998 (corresponding to the CN22 Zone of Roth, 1978 and the CC25c zones of Sissingh, 1977 and Perch-Nielsen, 1985).

Samples from Dereköy Section are characterised by low diversity calcareous nannofossil assemblages, with rare occurrences of very poorly preserved forms (Fig. 9). The main taxa are A. cymbiformis, C. ehrenbergii, Micula (M. staurophora, M. concava and M. swastica), P. cretacea and Watznaueria (W. barnesiae and W. fossacinta). Specimens occurring in minor amounts are referable to Biscutum, Chiastozygus, Retecapsa, and to the species $C$. reinhardtii, E. turriseiffelii, $M$. decoratus and $R$. bukryi. It was not possible to recognise marker species, but the occurrence of large specimens of A. cymbiformis, in significant amounts, and the unusual presence of the rare holococcolith R. bukryi, also recognised in the Epçeler Section, allows for the correlation between the two sections and the attribution of the Dereköy Section to the same late Maastrichtian age.

\section{Orbitoides from the Taraklı Formation}

Orbitoides from the Taraklı Formation in Epçeler and Dereköy (localities A-C) is represented by two morphologically distinct types; lenticular, symmetrical biconvex, rarely asymmetrical tests, assigned to $O$. ex. interc. gruenbachensis Papp-apiculatus Schlumberger, and biconcave- to flat ones, assigned to O. pamiri Meriç (Fig. 10). A comparison of the test diameter versus thickness of these species, and also that of $O$. 'medius' from the Maastrichtian of Arabian Plate, is shown in Fig. 11. Although both

(See figure on next page.)

Fig. 9 Calcareous nannofossils from the Epçeler A, B (a-n) and Dereköy (O-T) sections. a Arkhangelskiella cymbiformis, sample EPA7. b Biscutum constans, sample EPA7. c Cribrocorona gallica, sample EPA7. d Cribrosphaerella ehrenbergii, sample EPA6. e Cyclagelosphaera reinhardtii, sample EPA7. f Eiffellithus turriseiffelii, sample EPA11. g Lithraphidites quadratus, sample EPA11. h Microrhabdulus decoratus, sample EPA7. i Micula staurophora, sample EPA7. j Prediscosphaera cretacea, sample EPA6. k Retecapsa crenulata, sample EPA7. I Watznaueria barnesiae, sample EPA6. $\mathbf{m}$ Lithraphidites praequadratus, sample EPB9. $\mathbf{n}$ Eiffellithus gorkae, sample EPB9. o Arkhangelskiella cymbiformis, sample DE5. p Biscutum constans, sample DE1. q Cyclagelosphaera reinhardtii, sample DE1. r Eiffellithus turriseiffelii, sample DE5. s Micula staurophora, sample DE5. t Prediscosphaera cretacea, sample DE5 

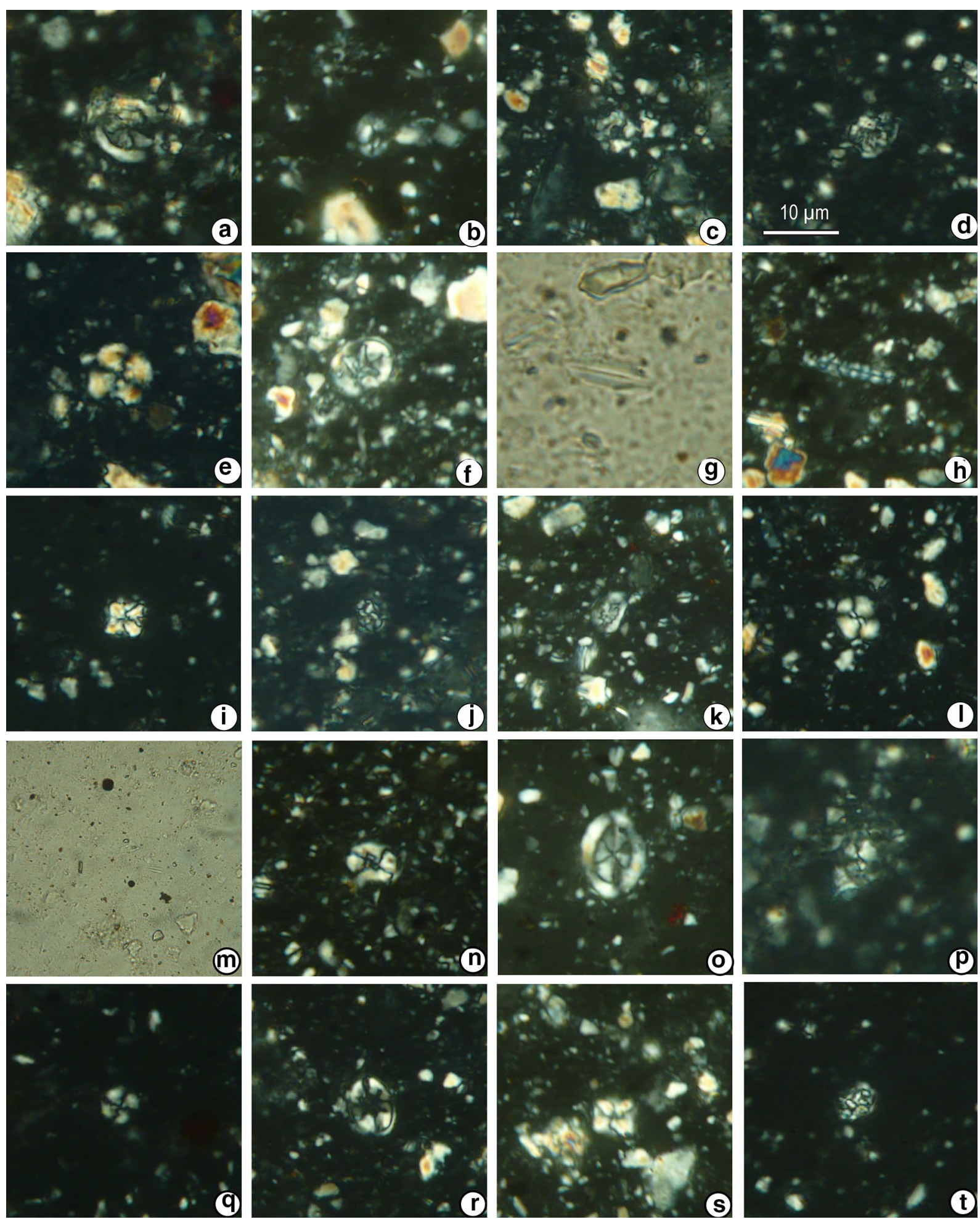

species have similar test dimensions, O. pamiri appears to be much thinner than $O$. ex. interc. gruenbachensisapiculatus, with a high test diameter-thickness ratio compared to any species discussed here. A comparison of the axial sections of both species is given in Figs. 12 and 13, where the development of lateral chamberlets, 


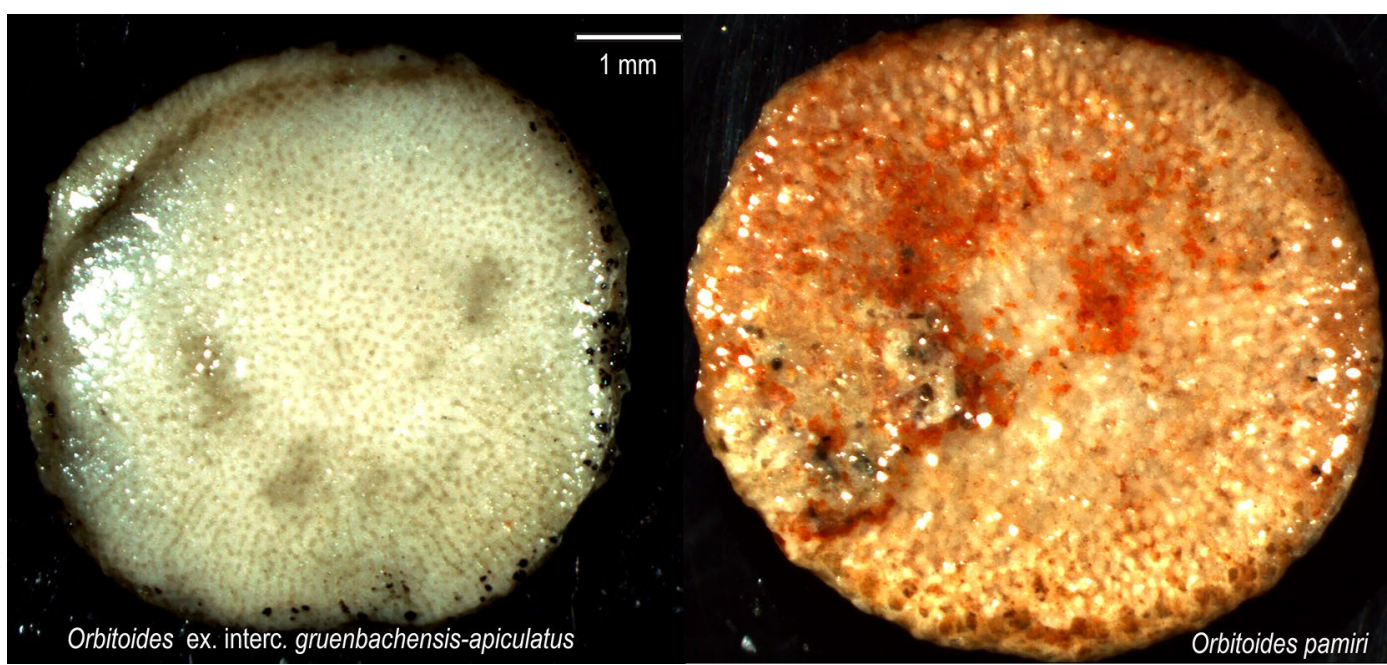

Fig. 10 External views of O. ex. interc. gruenbachensis Papp-apiculatus Schlumberger and O. pamiri from the Taraklı Formation

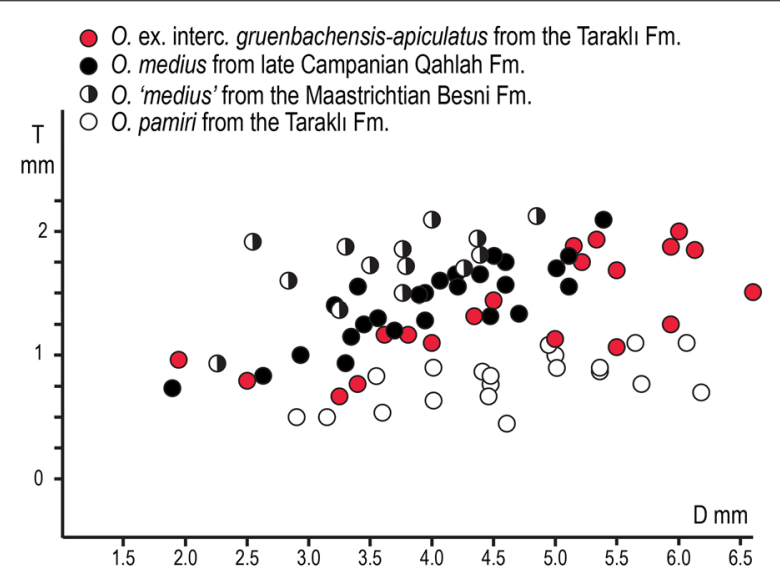

Fig. 11 Variation of test diameter $(D)$ and thickness $(T)$ in $O$. ex. interc. gruenbachensis Papp-apiculatus Schlumberger and O. pamiri Meriç from the Taraklı Formation and O. medius from the upper Campanian Qahlah Formation (Oman)

thickness of the equatorial layer and stolon system are well observed. The measurements are tabulated in Table 2.

\section{Orbitoides ex. interc. gruenbachensis Papp-apiculatus \\ Schlumberger}

In Epçeler A section, based on 21 specimens, test diameter of $O$. ex. interc. gruenbachensis-apiculatus varies between 2.95 and $6.8 \mathrm{~mm}$, with sample averages ranging between 3.7 and $5.10 \mathrm{~mm}$ (Fig. 11; Table 2). Test thickness varies between $0.65 \mathrm{~mm}$ and $1.95 \mathrm{~mm}$, with sample averages ranging between 0.96 and $1.41 \mathrm{~mm}$. Test diameter to thickness ratio varies between 2.74 and 5.36 with a sample average of 3.83 . The thickness of the equatorial layer (excluding the chamber wall) near its centre and periphery ranges between 75 and $165 \mu \mathrm{m}$ and 105.0 and $245 \mu \mathrm{m}$ with sample averages of 132.5 and $160.0 \mu \mathrm{m}$, respectively. Stolons connecting the equatorial chamberlets are about $20-25 \mu \mathrm{m}$ in diameter in the early stage of development and 35-40 $\mu \mathrm{m}$ in the later stages. Orbitoides ex. interc. gruenbachensis-apiculatus possess predominantly large bilocular embryonic apparatus, a characteristic embryonic chamber arrangement commonly observed in O. apiculatus (Figs. 14a-e and 15). The average size of the embryonic apparatus $(\mathrm{Li}+\mathrm{li})$ in seven samples from both stratigraphic sections varies between 854.8 and $935.0 \mu \mathrm{m}$ (Table 1 ). The average number of $E$ varies between 13.0 and 14.30. These populations are assigned to a transitional development stage between O. gruenbachensis Papp and O. apiculatus Schlumberger according to the biometric species limits proposed by van Hinte (1976), which is designated as O. ex. interc. gruenbachensis-apiculatus (Fig. 16).

\section{Orbitoides pamiri Meriç}

Orbitoides from the Epçeler B section is only represented by $O$. pamiri. Based on 19 specimens, test diameter varies between 2.9 and $6.17 \mathrm{~mm}$, with an average of $4.61 \mathrm{~mm}$ (Fig. 11; Table 2). Test thickness varies between $0.45 \mathrm{~mm}$ and $0.92 \mathrm{~mm}$, with an average of $0.69 \mathrm{~mm}$ in sample EPB5. Test diameter to thickness ratio varies between 4.33 and 10.2 with a sample average of 6.09 . The thickness of the equatorial layer (excluding the chamber wall) near its centre and periphery ranges between 85 and $150 \mu \mathrm{m}$ and 170.0 and $440 \mu \mathrm{m}$, respectively, with a sample average of $238.1 \mu \mathrm{m}$ in sample EPB5. Stolons connecting the 


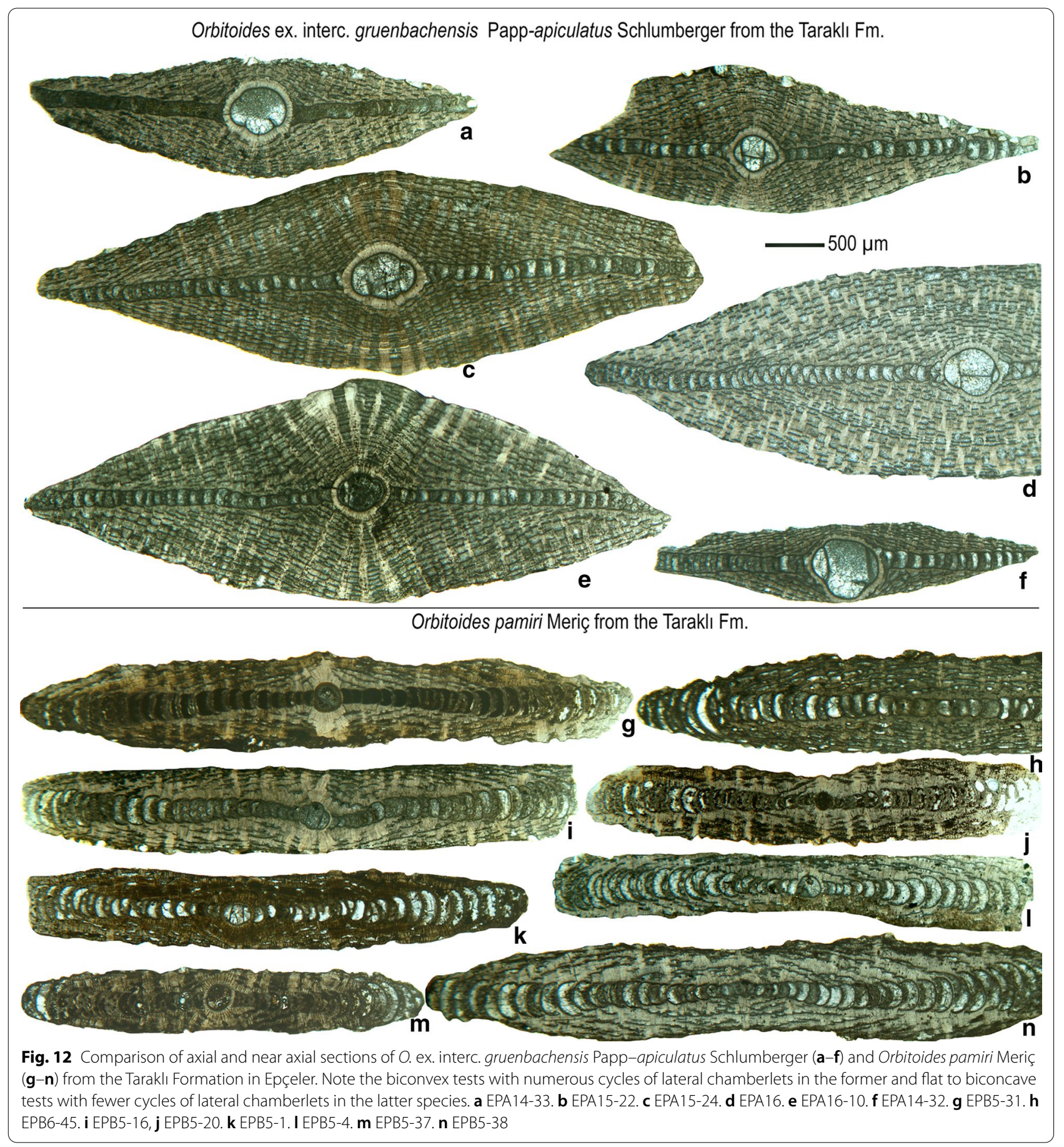

equatorial chamberlets are about $35-40 \mu \mathrm{m}$ in diameter in the late ontogenetic stages.

O. pamiri from Epçeler A, B and Dereköy sections possess invariably small tri- to quadrilocular embryonic apparatus commonly observed in O. tissoti and $O$. medius (Figs. 14f-k, 16, 17, and 18). The average size of the embryonic apparatus $(\mathrm{Li}+\mathrm{li})$ in nine samples from Epçeler A and B sections varies between 421.18 and $516.43 \mu \mathrm{m}$ (Table 1). The average number of $\mathrm{E}$ varies between 3.95 and 4.13. It is interesting to note that some specimen of $O$. pamiri yielded embryonic apparatus with 3 epi-embryonic chamberlets (Fig. 16i and l). 


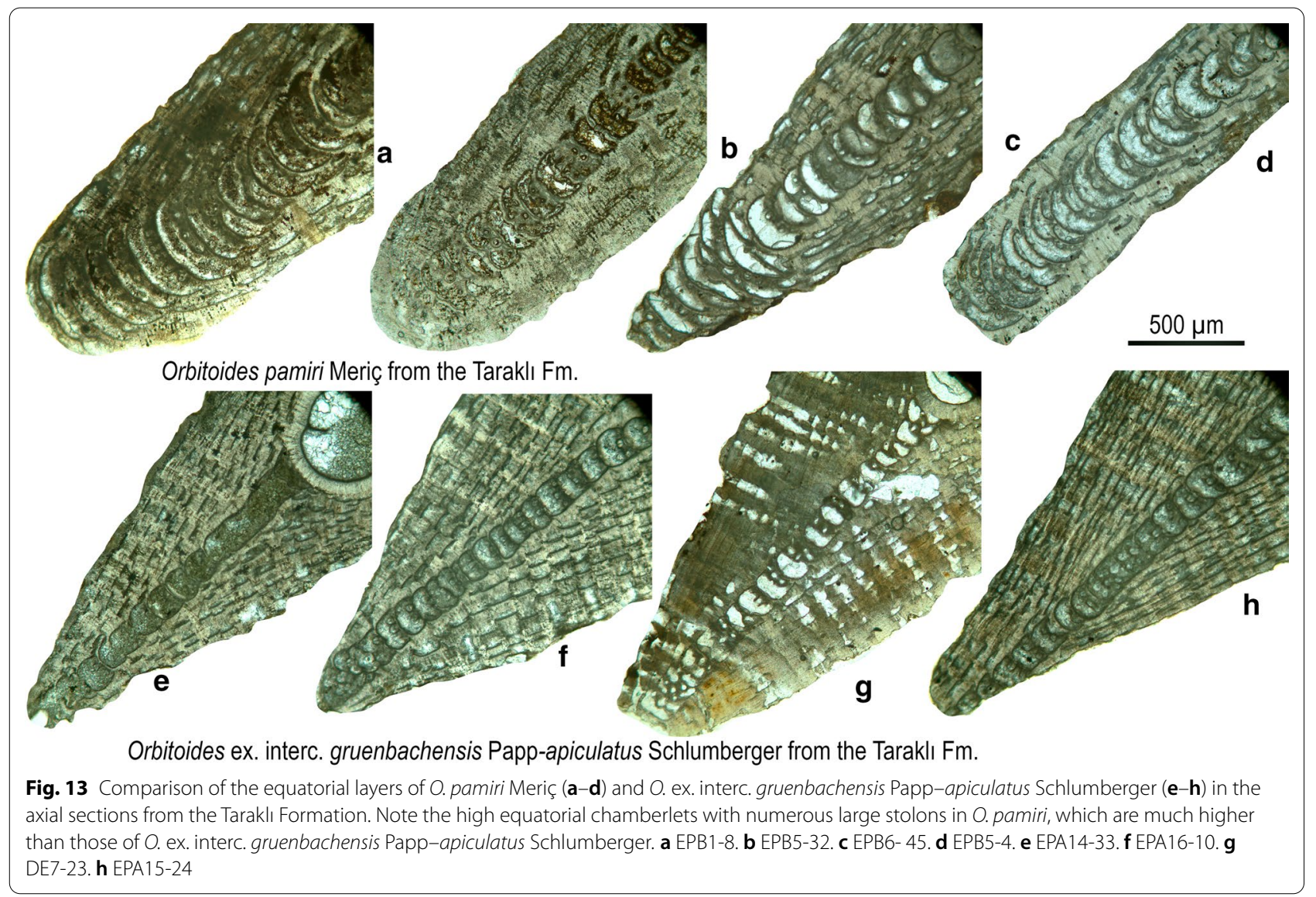

\section{Orbitoides from Terbüzek, Besni and Germav Formations}

Orbitoides specimens from the Terbüzek, Besni and Germav Formations (localities D-F) are represented by symmetrical biconvex, rarely asymmetrical tests with notably large central piles in the central part of the test. These specimens were assigned to O. megaloformis in Terbüzek and Germav Formations and to O. 'medius' in the Besni Formation.

\section{Orbitoides megaloformis Papp and Küpper}

Orbitoides specimens from the Terbüzek Formation (Locality D; samples TF2 and 5) yielded tri- to quadrilocular embryons. The size of the embryon in both samples varies between 415.0 and $1155 \mu \mathrm{m}$, and 315.0 and $1050 \mu \mathrm{m}$, with sample averages of 700.3 and $698.4 \mu \mathrm{m}$, respectively (Fig. 19; Table 1). The average number of epi-embryonic chamberlets are 9.13 and 8.6, respectively. This population is assigned to O. megaloformis, although, typologically, some specimens with small embryons and a few epi-embryonic chamberlets (e.g. TF2-18, TF2-33 in Fig. 19) are within the limits of O. medius. Lepidorbitoides from both samples invariably possess quadriserial nepionts, with a few adauxiliary chamberlets (adc) only in some several specimens (Fig. 19). In sample TF2, out of 52 specimens, only three with one and one specimen with two adauxiliary chamberlets were found. In sample TF5, only three specimens, out of 35 , with one adauxiliary chamberlets were found. These specimens with mean P, D, D/P and adc values of $98.65 \mu \mathrm{m}, 147.12 \mu \mathrm{m}$, 1.5 and 0.1 in sample TF2 and $96.0 \mu \mathrm{m}, 145.71 \mu \mathrm{m}, 1.52$ and 0.09 in sample TF5, respectively, were assigned to Lepidorbitoides bisambergensis (Jaeger) (Fig. 19).

Most Orbitoides specimens in the Germav Formation (Locality F; sample GA64) possess predominantly tri- to quadrilocular embryons. One single specimen yielded a bilocular embryon, typical for O. apiculatus (specimen GA64-84 in Fig. 19). Embryon size ranges between 410 and $910 \mu \mathrm{m}$, with the sample average of $596.4 \mu \mathrm{m}$. The mean $E$ value varies between 4 and 13, with an average of 7.75. This population is assigned to O. 'megaloformis', although, in a typological sense, specimen with a bilocular embryon may be assigned to O. apiculatus.

\section{Orbitoides 'medius' (d'Archiac)}

Orbitoides specimens from the Besni Formation (Locality E; samples TC6, 7, 8, 9, 10 and 13) are characterised by having strongly biconvex tests with large piles in their central parts (Fig. 20). The asymmetrical tests 

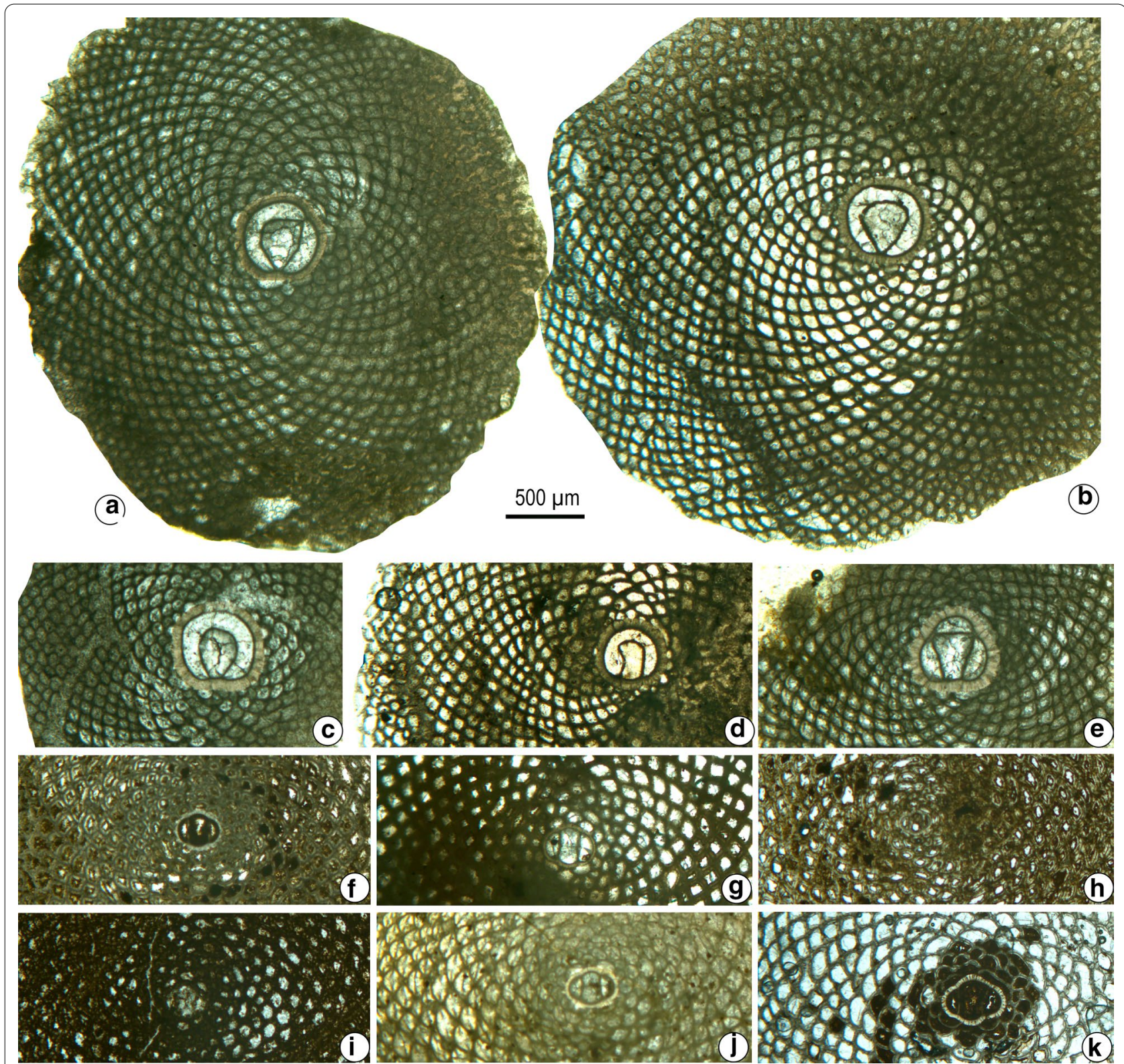

Fig. 14 Equatorial sections of O. ex. interc. gruenbachensis-apiculatus (a-e) and O. pamiri (f-k) from the Taraklı Formation in Epçeler A and Dereköy sections. a EPA18-4. b DE7-17. c EPA18-5. d DE7-4, e EPA19-2. f DE7-21. g EPA19-1. h EPA18-1. i EPA18-2. jEPA18-3. k EPA17-2

occur rarely. Based on 14 specimens from samples TC7 and 13, test diameter varies between 2.25 and $4.41 \mathrm{~mm}$, with samples averages of 3.88 and $3.3 \mathrm{~mm}$, respectively (Table 2). Test thickness varies between 0.97 and $2.12 \mathrm{~mm}$, with sample averages of 1.72 and $1.77 \mathrm{~mm}$. Test diameter to thickness ratio varies between 2.02 and 2.49 and 1.73 and 2.3 with a sample average of 2.27 and 1.89. A comparison of the test diameter versus thickness of these specimens and those of $O$. medius from the Campanian of Oman, and $O$. pamiri and $O$. ex. interc. gruenbachensis-apiculatus from the Taraklı Formation is shown in Fig. 11. The thickness of the equatorial layer (excluding the chamber wall) near its centre and periphery ranges between 140 and $190 \mu \mathrm{m}$ and 130 and $165220 \mu \mathrm{m}$ and 220 and $285 \mu \mathrm{m}$ and 215 and $290 \mu \mathrm{m}$, respectively, with sample averages of 160.0 and $146.6 \mu \mathrm{m}$ and 252.5 and $249.1 \mu \mathrm{m}$ (Table 2). Stolons connecting the equatorial chamberlets are about $30-40 \mu \mathrm{m}$ in diameter in the late stage of ontogenetic development. The embryonic apparatus consist of small tri- to quadrilocular 


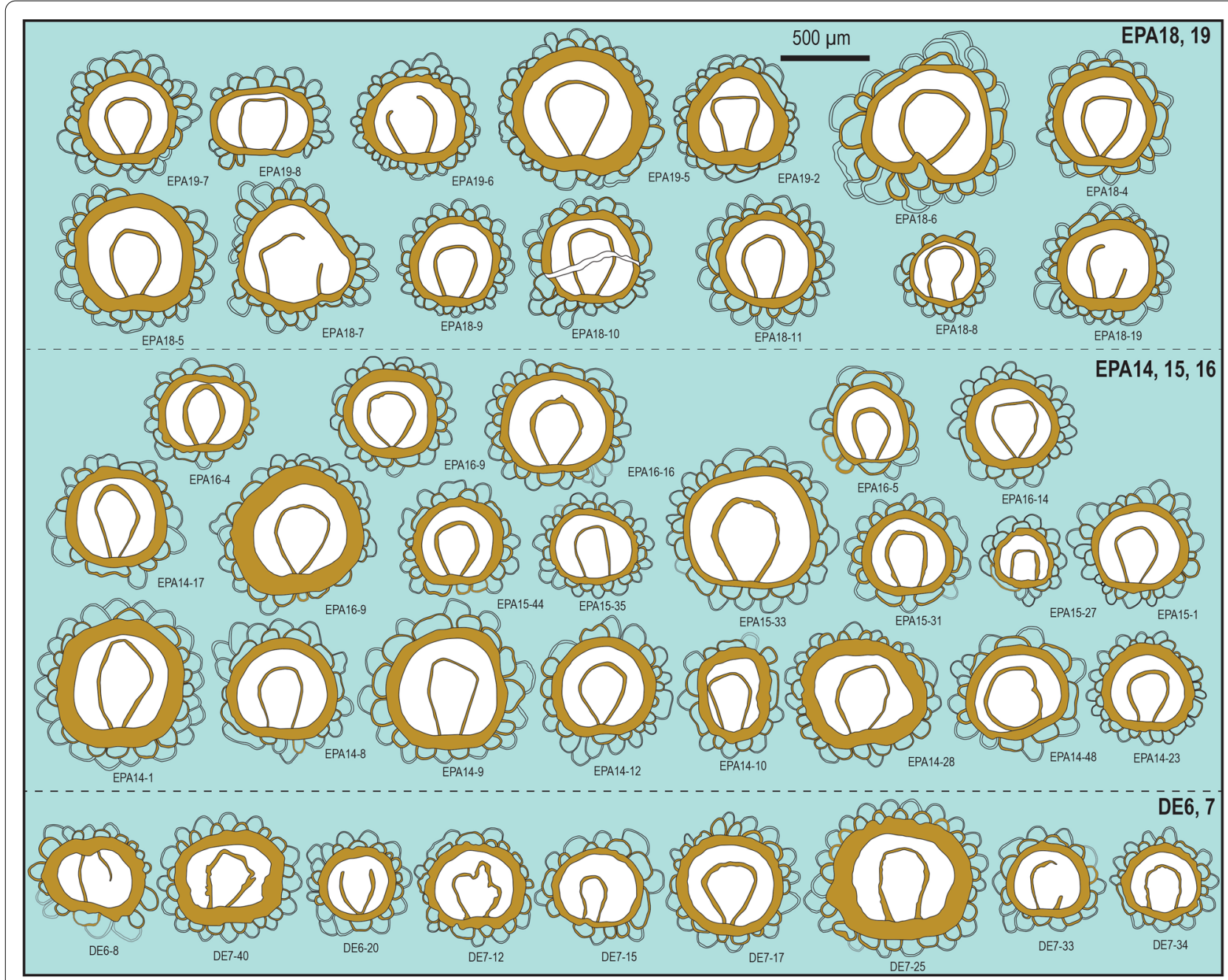

Fig. 15 Line drawings of the embryonic-nepionic stages of $O$. ex. interc. gruenbachensis Papp-apiculatus Schlumberger from the Taraklı Formation in Epçeler A and Dereköy sections

embryons, within the biometric limits of O. medius, surprisingly much smaller than those from the underlying Terbüzek Formation (Fig. 19; Table 1). The size of the embryonic apparatus based on 144 specimens in 6 samples (TC6, 7, 8, 9, 10 and 13) varies between 345.0 and $950 \mu \mathrm{m}$, with sample averages ranging between 461.7 and $554.4 \mu \mathrm{m}$. The average number of epi-embryonic chamberlets ranges between 4.4 and 5.41 . This population is assigned to $O$. 'medius', although, typologically, some specimens with larger embryons (e.g. TC8-47, TC6-33 in Fig. 19) are within the limits of $O$. megaloformis).

\section{Orbitoides from the Beyobası Formation (Haymana Basin, Central Turkey)}

Most of the specimens (34 out of 36) yielded bilocular and two yielded tri- to quadrilocular embryons (Fig. 8c, specimen DEG19-38). The size of the embryonic apparatus in bilocular specimens ranges between 665 and $1380 \mu \mathrm{m}$, with the sample average of $1023.4 \mu \mathrm{m}$ (Figs. 8c and 16, Table 1). The mean $E$ value varies between 11 and 20 , with an average of 14.94 . This population is assigned to $O$. apiculatus, although, in a typological sense, 2 specimens with small embryons may be assigned to $O$. 'medius'.

\section{Orbitoides from the Qahlah and Simsima Formations (Oman)}

Orbitoides from the upper Campanian Qahlah Formation (locality G) is represented lenticular, symmetrical biconvex, rarely asymmetrical tests (Figs. 11, 21). These specimens are within the biometric limits of O. tissoti and $O$. medius and are assigned to O. medius considering the presence of well-developed lateral chamberlets and the number of epi-embryonic chamberlets (Table 2). A 


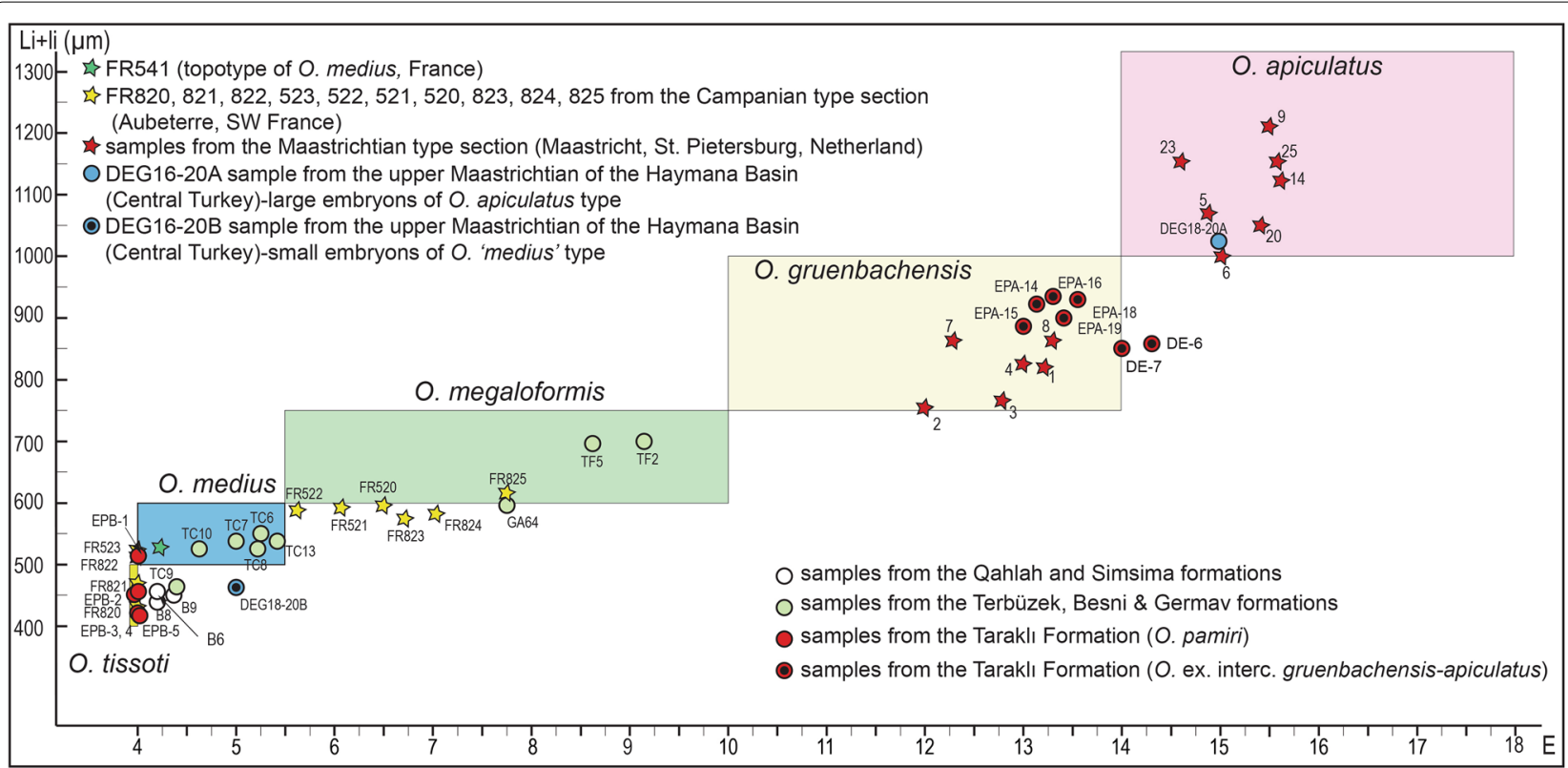

Fig. 16 Scatter diagram showing the relation between the average number of epi-embryonic chamberlets (E) and embryon size ( $L i+l i)$ of the studied Orbitoides populations from Epçeler and Dereköy. Data from the Campanian and Maastrichtian type sections and the upper Maastrichtian Beyobası Formation (samples DEG 16-20) from the Haymana Basin are also shown. Species limits after van Hinte (1976). Data from the Campanian type section (samples FR 820, 821, 822, 523, 522, 521, 520, 823, 824 and 825 in ascending stratigraphic order) are from van Hinte (1966b) and those from the Maastrichtian type section (samples 1-9, 12, 14, 23, 25) are from Baumfalk and Willemsen (1986)

comparison of the test diameter versus thickness of this species with O. 'medius' from the Maastrichtian of Arabian plate and $O$. ex. interc. gruenbachensis-apiculatus from the Taraklı Formation is shown in Fig. 11. A comparison of the axial sections of O. medius and O. pamiri, which have a similar embryonic apparatus, is presented in Fig. 21. In sample BC6, the thickness of the equatorial layer near test centre and periphery ranges between 85 and $140 \mu \mathrm{m}$ and 130 and $205 \mu \mathrm{m}$, with sample averages of 113.8 and $157.1 \mu \mathrm{m}$, respectively (Table 2). The stolons at the peripheral equatorial chamberlets are about $25-30 \mu \mathrm{m}$ in diameter. The embryonic apparatus in all specimens is tri- to quadrilocular and shows a range of size between 260 and $690 \mu \mathrm{m}$, with sample averages ranging between 440 and $450 \mu \mathrm{m}$ (Fig. 21; Table 1). The average number of epi-embryonic chamberlets ranges between 4.2 and 4.36 .

The rare Orbitoides from the lower part of the Simsima Formation at Jabal Huwayyah (samples B28 and B32) yielded two types of embryons: a large, multilocular embryons and small ones with typical tri- to quadrilocular appearance in equatorial sections. In sample B28, the large multilocular embryon with $\mathrm{Li}+\mathrm{li}$ value of $1710.0 \mu \mathrm{m}$ is assigned to O. gensacicus, and two specimens possessing small, tri- to quadrilocular embryons with an average $\mathrm{Li}+\mathrm{li}$ value of $477.5 \mu \mathrm{m}$ are assigned to O. 'medius' (Fig. 22). These specimens have only 4 epi-embryonic chamberlets. In sample B32, two Orbitoides specimens are characterised by a large embryon with an average size of $1660 \mu \mathrm{m}$ (Fig. 21). The number of epi-embryonic chambers could not be counted. These specimens are assigned to O. gensacicus. Two specimens characterised by trilocular embryons, with an average $\mathrm{Li}+\mathrm{li}$ value of $527.5 \mu \mathrm{m}$ are assigned to O. 'medius' (Fig. 22).

\section{Discussion}

The new data presented herein permit us to interpret the Maastrichtian Orbitoides from the Central Sakarya Basin and Arabian Platform in a broader Tethyan context for the first time and allow us a comparison with the records from Western Europe. In general, our data from various Maastrichtian localities in the Arabian Platform (Turkey and Oman) and Central Turkey show the predominance of 'O. medius'-like specimens with small tri- to quadrilocular embryons and fewer epi-embryonic chamberlets, previously considered characteristic for the Campanian (Fig. 6). These specimens are characterised by two morphological types: biconvex tests $(O$. 'medius'), and flat to biconcave tests (O. pamiri) and do not show any sign of reworking in terms of test features and composition of the associated foraminifera. Orbitoides are intact and well preserved without any sign of abrasion or decortication. 


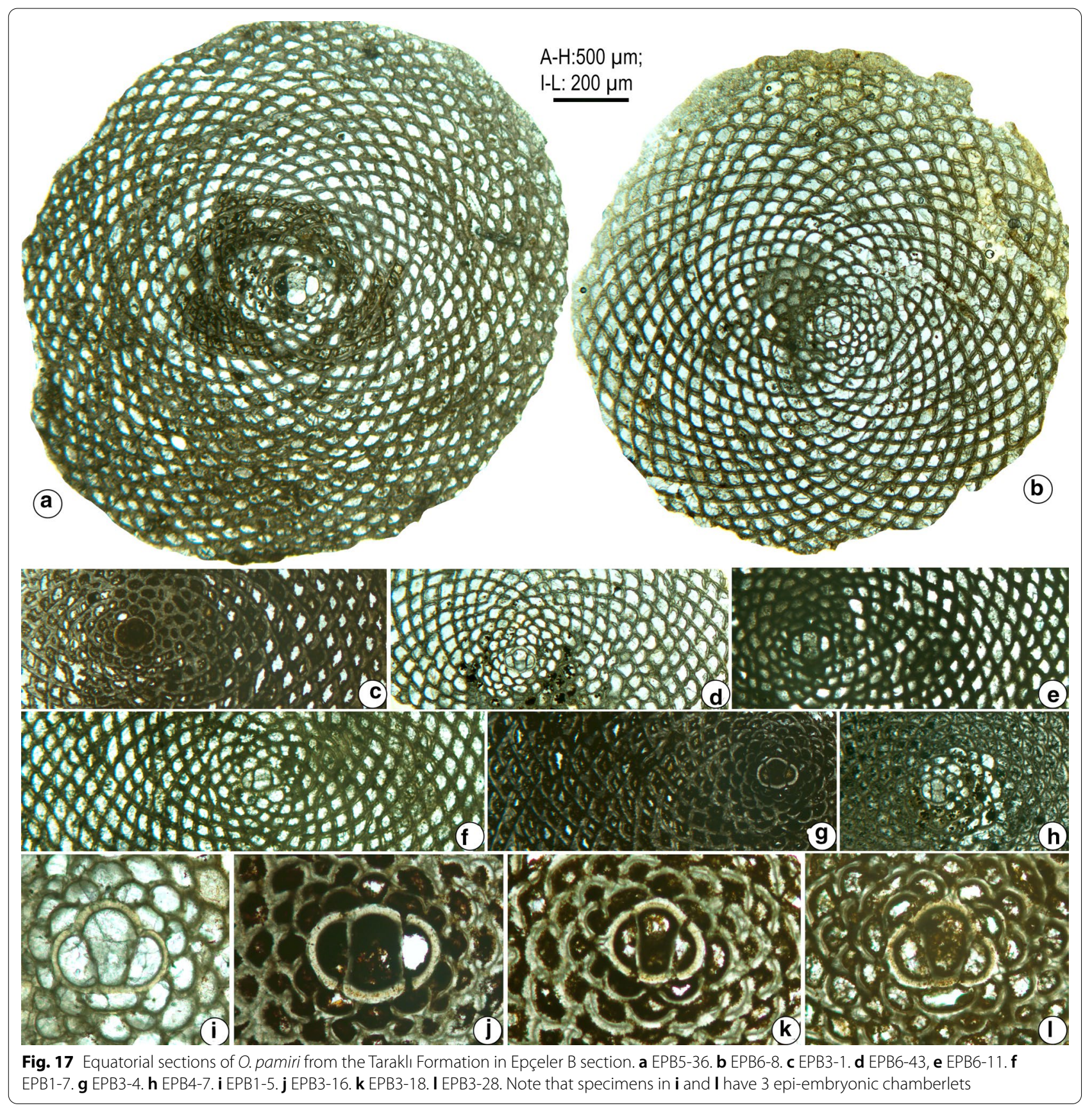

No older foraminifera (e.g. Campanian foraminifera) were found in association with this species. In our material, O. pamiri is very abundant in the Taraklı Formation and all specimens are flat and/or biconcave in shape.

The Arabian Platform sequence in Southeastern Turkey yields $O$. megaloformis-L. bisambergensis assemblages in its lower part (Terbüzek Formation) and an $O$. 'megaloformis' $-L$. gr. minor-socialis assemblage in its upper part (Germav Formation) (Özcan, 1994; Fig. 17). The Maastrichtian Orbitoides present in this succession are characterised by biconvex tests with similar features to those recorded in some localities in Iran and Oman (Abdelghany, 2003; Payandeh et al. 2019). Considering the mean values of embryon size $(\mathrm{Li}+\mathrm{li})$ and number of epi-embryonic chamberlets (E), an evolutionary trend is not observed. Contrary to the principle of nepionicembryonic acceleration, the most 'evolved' populations occur in the Terbüzek Formation and 'primitive' ones in the overlying beds of the Besni Formation which contains biconvex tests with predominantly O. medius-type 


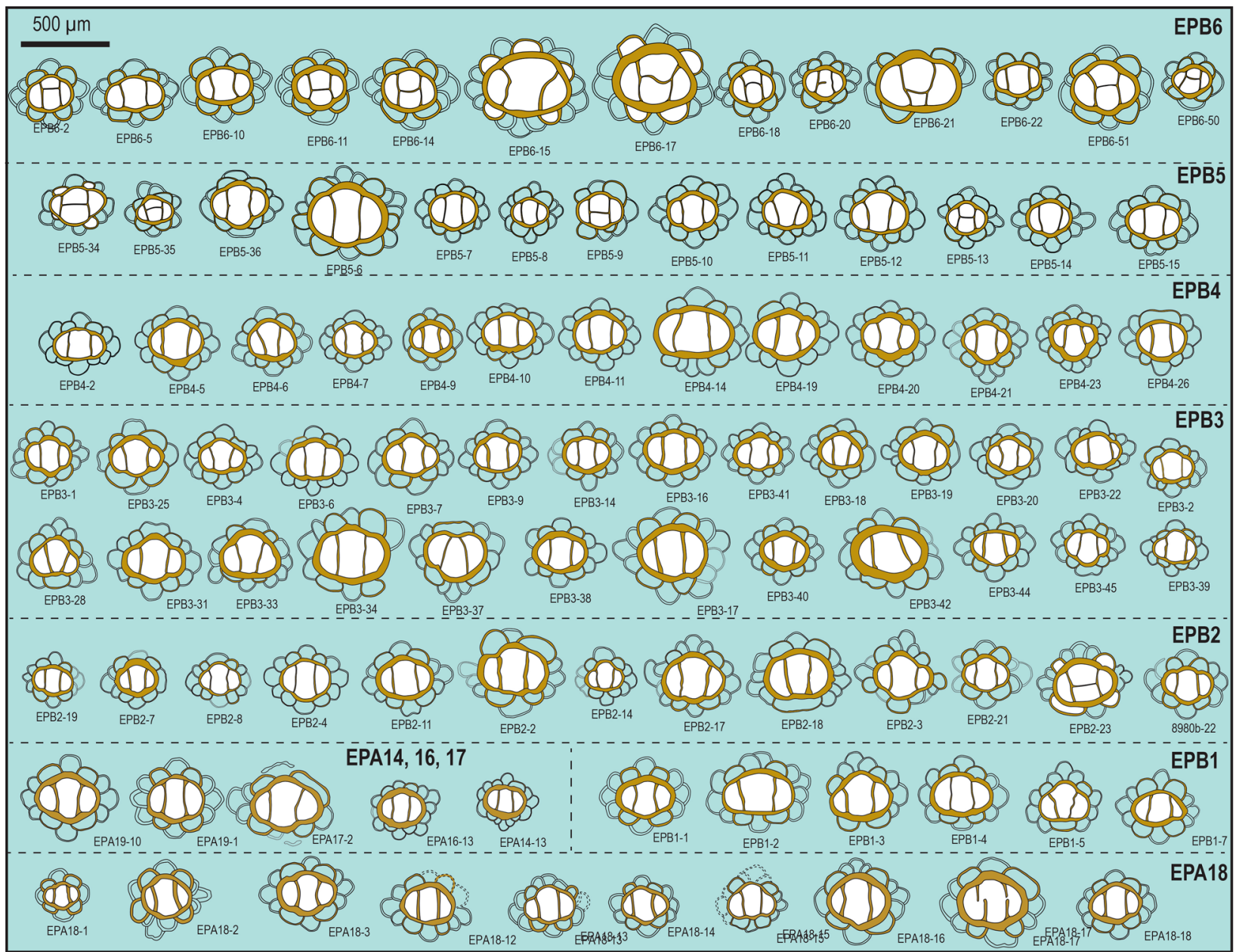

Fig. 18 Line drawings of the embryonic-nepionic stages of O. pamiri Meriç from the Taraklı Formation in Epçeler A, B and Dereköy sections

embryonic apparatus, associated with $S$. calcitrapoides, O. anatoliensis, S. cf. orbitoidiformis, and C. cf. mamillatus, Loftusia spp. (Özcan, 1993, 2007). The Germav Formation contains an $O$. 'megaloformis' assemblage with few specimens possessing $O$. apiculatus-type bilocular embryonic apparatus (Fig. 19).

In addition to the advanced specimens of the main Orbitoides lineage, which are here assigned to a transitional stage from O. gruenbachensis to O. apiculatus, the Maastrichtian Taraklı Formation yielded invariably flat to biconcave tests possessing very small embryonic apparatus (in the range of $O$. tissoti and O. medius) and a low number of epi-embryonic chambers (with predominantly 4 chamberlets), thus, very much resembling the Campanian species $O$. tissoti and $O$. medius in equatorial sections. These specimens, however, have well-developed lateral layers, making them distinct from $O$. tissoti, a very thick equatorial layer, almost twice as thick as that those of the biconvex specimens, and numerous large stolons connecting the equatorial chamberlets. Moreover, the number of lateral chamberlet cycles is much less than the biconvex Orbitoides specimens (compare the specimens in Figs. 12 and 13). In previous studies with well-documented morphometric data from Europe and Turkey, Orbitoides tests were invariably reported to be symmetric to asymmetrical in outline, with rare occurrences of plano-convex tests (Baumfalk \& Willemsen, 1986; Caus et al. 1996; Eggink \& Baumfalk, 1983; Meriç, 1965; Özcan, 1993). These variations were always interpreted as ecophenotypic, linked with prevailing environmental conditions (Eggink \& Baumfalk, 1983; van Gorsel, 1978). The flat to biconcave specimens with small embryons from the Taraklı Formation strongly resemble to $O$. apiculata pamiri first described by Meriç (1974) from the upper Maastrichtian beds from SW Turkey. Meriç (1974) reported the associated foraminifera as $O$. apiculatus, $O$. medius, L. minor, O. macroporus, $S$. calcitrapoides, $L$. anatolica and H. beotica. A comparison of the axial sections 


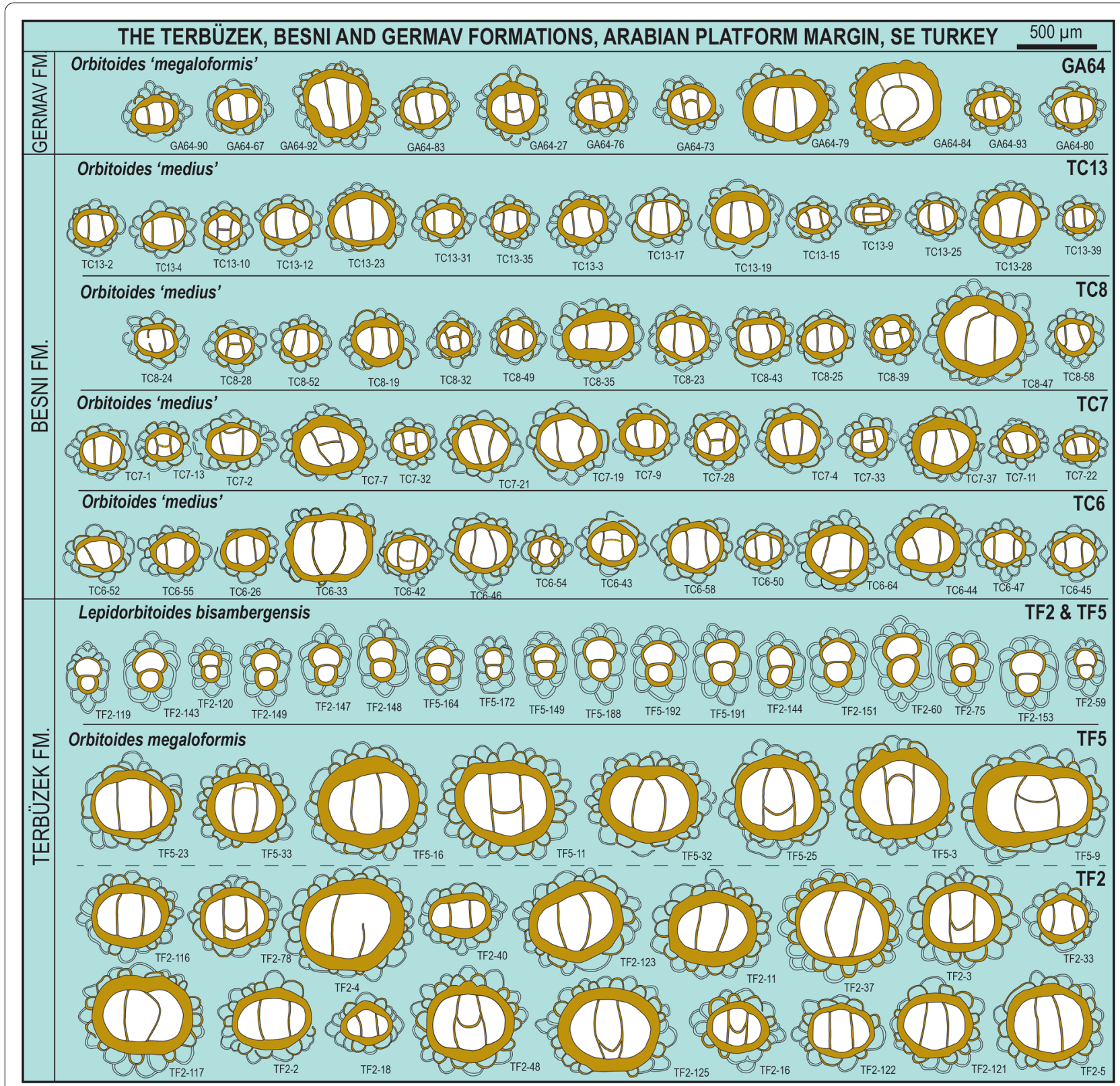

Fig. 19 Line drawings of the embryonic-nepionic stages of Orbitoides (and Lepidorbitoides) from the Terbüzek, Besni and Germav and formations, SE Turkey, Arabian Platform margin

of our flat to biconcave specimens (O. pamiri) with $O$. medius from the upper Campanian of Oman (Kayğllı et al. $2021)$ is given in Fig. 21. Both species have similar morphometric values for the size of the embryon and number of epi-embryonic chamberlets (Table 1). O. medius differs from O. pamiri in having biconvex tests, numerous lateral chamberlets and a thinner equatorial layer.

Based on the above data, we assert that biconvex and flat to biconcave Orbitoides populations from the upper Maastrichtian of Central Sakarya Basin and Taurides do not belong to the main Orbitoides evolutionary lineage. We think that $O$. 'medius' and $O$. pamiri represent offshoots from the main lineage in the Maastrichtian (Fig. 23), forming side-lines to the main lineage. These offshoots probably took place at levels corresponding to $L$. minor and/or L. socialis in the Maastrichtian since the record of the genus until the level with L. bisambergensis appears to be consistent with the species succession of O. medius-O. megaloformis-O. gruenbachensis in the Tethys. Well-dated Campanian deposits in two 


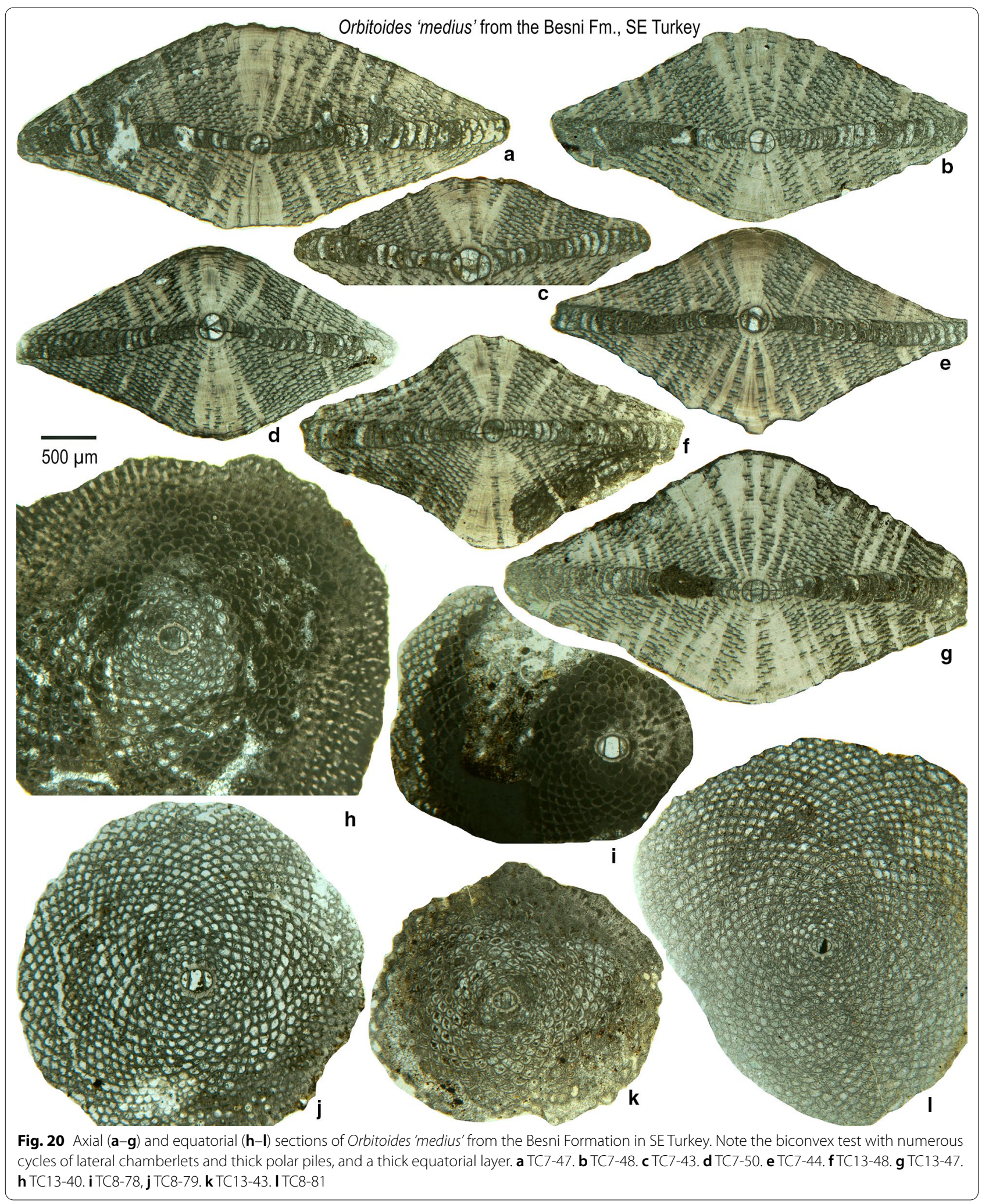




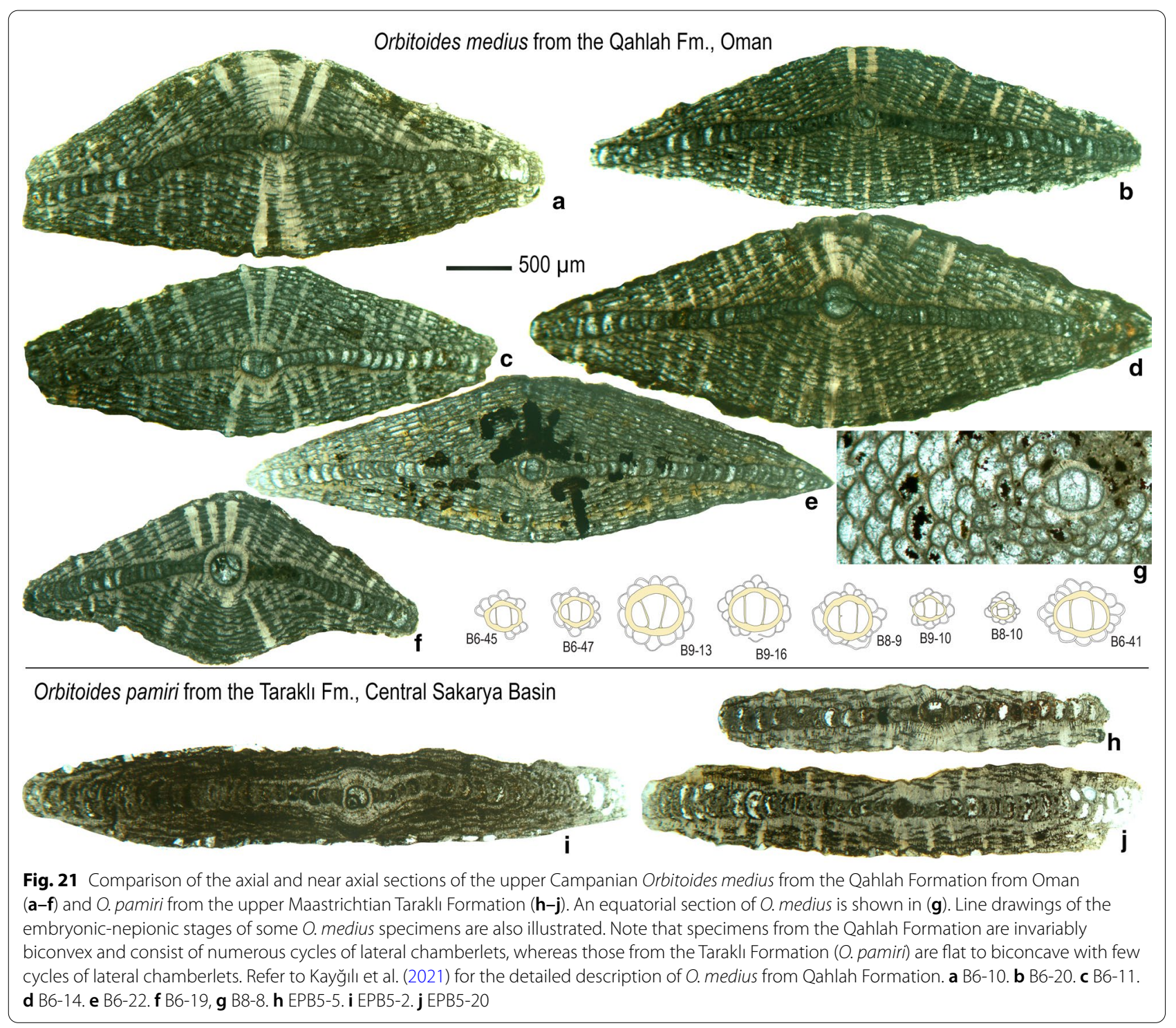

localities in Turkey yielded data consistent with this scheme. Helicorbitoides voigti van Gorsel and Pseudosiderolites vidali (Douvillé) recorded from the Tonya Formation in NE Turkey are associated with O. medius (Özcan et al. 2019), and O. megaloformis (Erdem et al. 2021), consistent with the record at the Campanian type section at Aubeterre. Caus et al. (1996) reported an O. gruenbachensis population from Maurens (Spain) associated with $L$. bisambergensis. This population does not contain $O$. medius-type embryons. We think that these inconsistent variations and widespread and common occurrence of flat to biconcave tests in at least two geographically separate regions in Turkey cannot simply be explained by environmentally induced morphological changes.
The principle of nepionic-embryonic acceleration demonstrated in many orbitoidal groups (Drooger, 1993) is also applicable in Orbitoides as recorded from single and separate sections from the late SantonianMaastrichtian time interval in Western Europe. Nonetheless, our data also imply the significance of test features not only related with the equatorial layer but also lateral layers and overall test morphology in general. The biconvex specimens from the upper Maastrichtian of the Haymana Basin in Central Turkey were provisionally assigned to $O$. 'medius' because of their great resemblance to this species on the morphometric grounds (Özcan \& Özkan-Altıner, 1997) and their distinction as a separate species from $O$. pamiri requires a detailed study. 


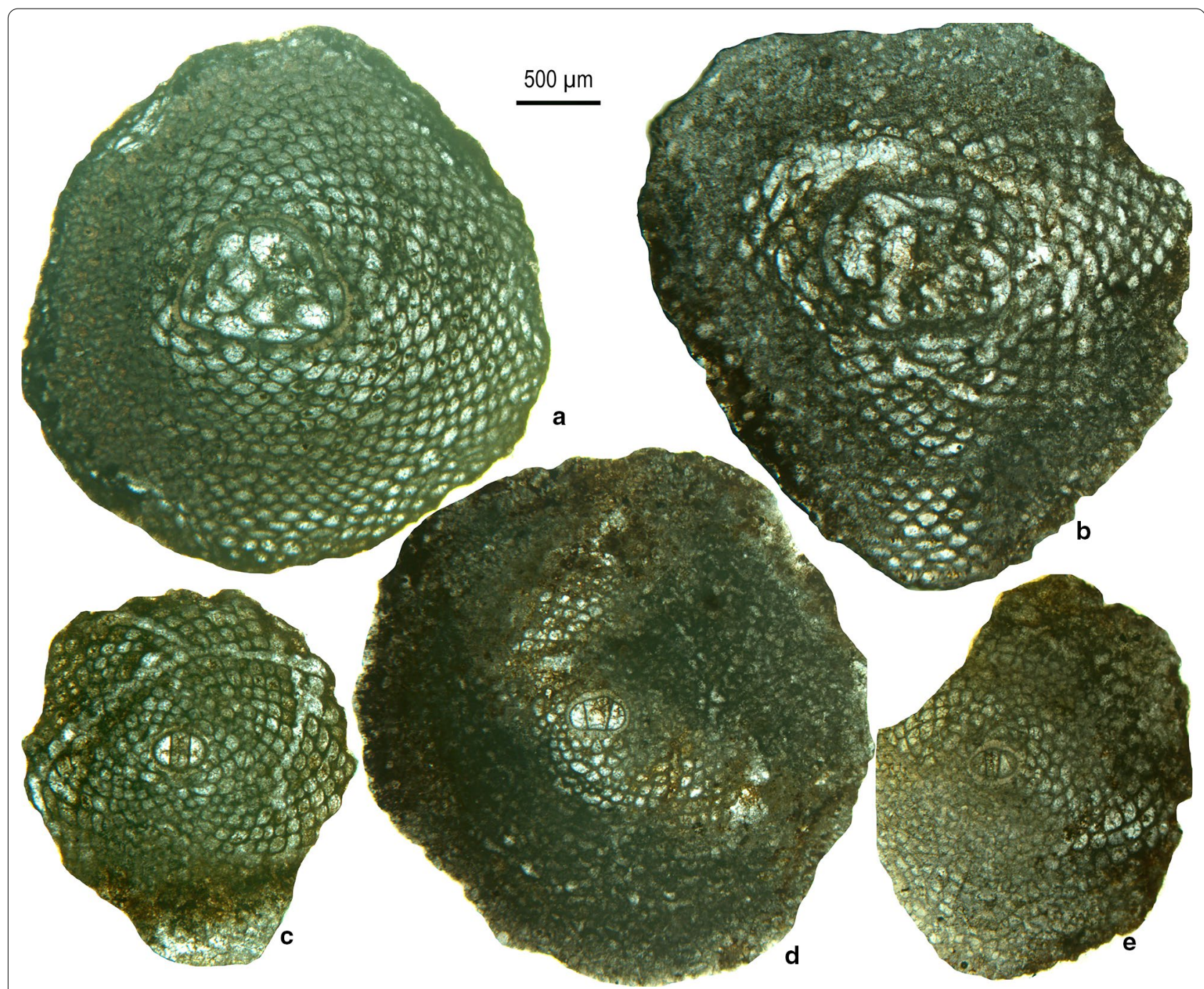

Fig. 22 Equatorial sections of O. gensacicus (a-b) and O. 'medius' (c-e) from the Simsima Formation in the Buraymi region, Oman. a B28-27. b B32-9. c B32-20. d B32-8. e B28-50

\section{Conclusions}

The hypothesis that a distinct separate lineage of Maastrichtian Orbitoides occurs in addition to the classic lineage formed by progressive evolution of key biometric characteristics (notable $\mathrm{E}$ and $\mathrm{Li}+\mathrm{li}$ ) is supported by:

1. In Maastrichtian-aged sediments of the Besni Formation of Southeastern Turkey, Orbitoides biometrically similar to O. medius occur, overlying the Terbüzek Formation with $O$. megaloformis, and underlying the Germav Formation with O. megaloformis and possible $O$. apiculatus. We refer to such forms with the informal name $O$. 'medius', to indicate that whilst they are very similar to $O$. medius in morphometric terms they represent a distinctively young retrograde or perhaps long-lived lineage that requires further study.

2. Within the Taraklı Formation of the Central Sakarya Basin, large biconvex specimens, with relatively large, complex embryons, referable to $O$. ex. interc. gruenbachensis-apiculatus, occur alongside flat-biconcave Orbitoides, with relatively small simple embryons in the biometric range of $O$. medius. We refer these to the overlooked species $O$. pamiri on the distinctive combination of morphology and embryon size and complexity.

3. Limited records of probable $O$. 'medius' occurring alongside $O$. apiculatus are also known from the Maastrichtian sediments of the Haymana Basin of Central Turkey. 


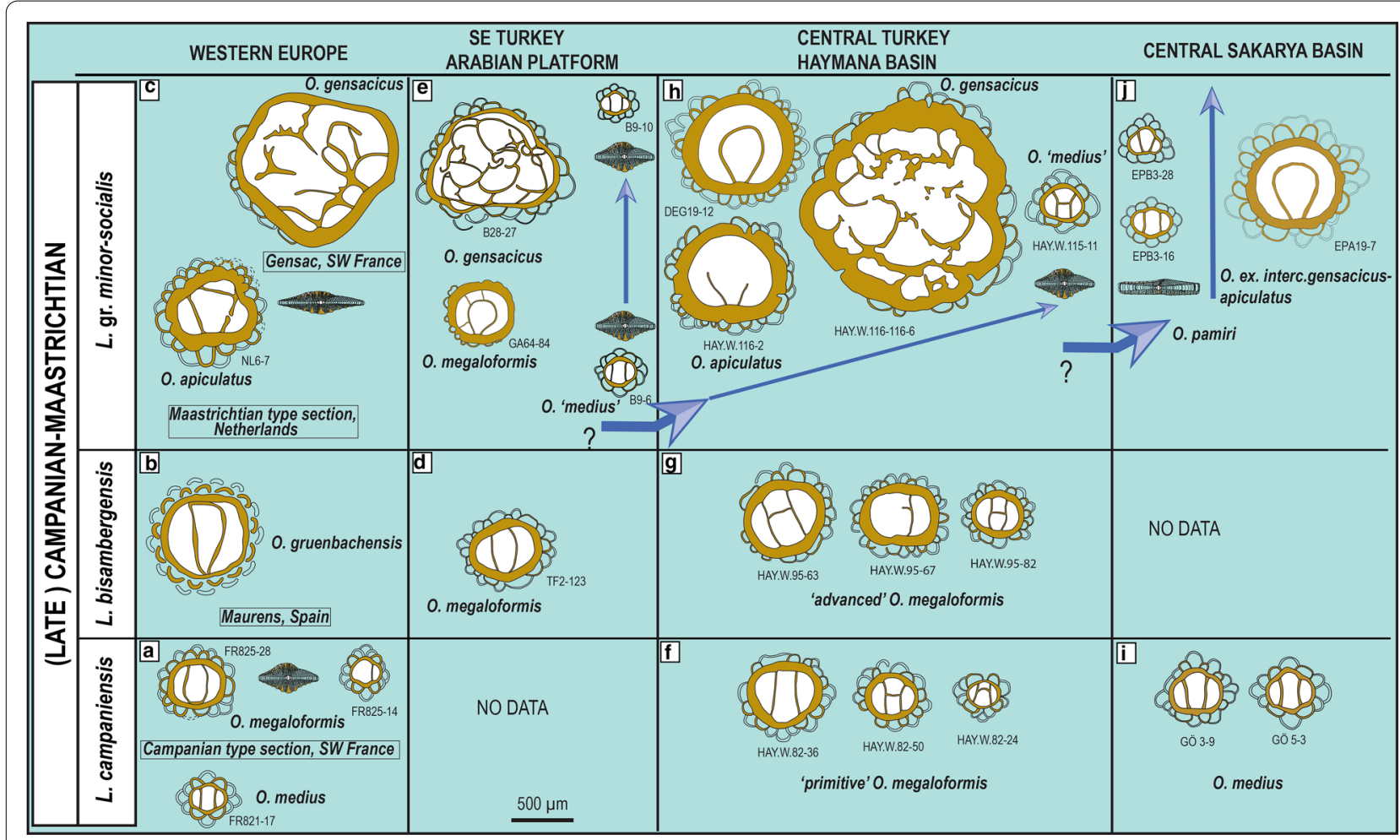

Fig. 23 Panel showing the tentative relations of Orbitoides species from the late Campanian to late Maastrichtian along the Arabian Plate margin, Turkey and Western Europe. Arrows show possible offshoots from the main Orbitoides lineage in the Maastrichtian, represented by 0 . 'medius' and O. pamiri. Orbitoides gensacicus from Gensac is not into scale. Data from Campanian and Maastrichtian type sections and from Gensac (SW France) are from van Hinte (1966b) and Eggink and Baumfalk (1983). The O. gruenbachensis population from Maurens, Spain is from Caus et al. (1996). The prefix 'GÖ' is for Orbitoides medius populations from the upper Campanian of the Central Sakarya Basin (unpublished data of EÖ and AOY). Details of samples HAY.W.82, 95, 115, 116 from the Haymana Basin are given in Özcan and Özkan-Altıner (1997)

4. O. medius is known from the Campanian Qahalah Formation of Oman, whilst the overlying Maastrichtian Simsima Formation yields O. 'medius'.

The recognition of $O$. 'medius' in undoubtedly Maastrichtian strata invites investigation of past records of $O$. medius. For example, this species has often been reported from Maastrichtian strata in the Middle East (e.g. Payandeh et al. 2019; Rahaghi, 1976; Schlagintweit et al. 2016) and Italy (Chiocchini et al. 2012). These records need to be re-examined to assess whether (i) these occurrences can be verified as O. medius; and (ii) if they are genuine Maastrichtian records.

Retrograde evolution within Orbitoides has been reported previously from the Caribbean bioprovince. There Mitchell (2005) reports the occurrence in uppermost Maastrichtian strata of a form he terms "Orbitoides cf. megaloformis". Biometrically, this taxon would appear very similar to O. megaloformis from typically upper Campanian strata (Fig. 7). This could be a further example of parallel lineages of Orbitoides occurring in the Maastrichtian, although it should be noted that the
Caribbean is a separate bioprovince from the Mediterranean and Arabian Tethys (Goldbeck, 2007).

The recognition of multiple lineages of Maastrichtian Orbitoides requires the integration of both morphometric analysis of embryon features coupled with consideration of external morphologies, that can be demonstrated not be simply ecophenotypic. Hence, a combination of morphometric and typological approaches can be beneficial for recognising the speciation of Late Cretaceous Orbitoides and identifying parallel evolutionary lineages.

\section{Appendix}

Taxonomic list of the calcareous nannofossils recognised in the samples from Epçeler and Dereköy sections. All the references below are reported in http://www.mikro tax.org/Nannotax3

Arkhangelskiella cymbiformis Vekshina, 1959.

Biscutum constans (Górka, 1957) Black in Black and Barnes, 1959. 
Biscutum ellipticum (Górka, 1957) Grün in Grün and Allemann, 1975.

Ceratolithoides aculeus (Stradner, 1961) Prins and Sissingh in Sissingh, 1977

Chiastozygus Gartner, 1968.

Cribrocorona gallica (Stradner, 1963) Perch-Nielsen, 1973.

Cribrosphaerella ehrenbergii (Arkhangelsky, 1912) Deflandre in Piveteau, 1952.

Cyclagelosphaera reinhardtii (Perch-Nielsen, 1968)

Romein, 1977.

Eiffellithus gorkae Reinhardt, 1965.

Eiffellithus turriseiffelii (Deflandre in Deflandre and

Fert, 1954) Reinhardt, 1965.

Lithraphidites quadratus Bramlette and Martini, 1964.

Lithraphidites praequadratus Roth, 1978

Markalius inversus (Deflandre in Deflandre and Fert,

1954) Bramlette and Martini, 1964.

Microrhabdulus decoratus Deflandre, 1959.

Micula concava (Stradner in Martini and Stradner,

1960) Verbeek, 1976.

Micula praemurus (Bukry, 1973) Stradner and Steinmetz, 1984.

Micula staurophora (Gardet, 1955) Stradner, 1963.

Micula swastica Stradner and Steinmetz, 1984.

Prediscosphaera cretacea (Arkhangelsky, 1912) Gartner, 1968.

Prediscosphaera ponticula (Bukry, 1969) Perch-Nielsen, 1984.

Retecapsa angustiforata Black, 1971.

Retecapsa crenulata (Bramlette and Martini, 1964)

Grün in Grün and Allemann, 1975.

Russellia bukryi Risatti, 1973.

Zeugrhabdotus Reinhardt, 1965.

Watznaueria barnesiae (Black in Black and Barnes, 1959) Perch-Nielsen, 1968.

Watznaueria fossacincta (Black, 1971) Bown in Bown and Cooper, 1989.

\section{Acknowledgements}

Material from the Taraklı Formation in Central Turkey was collected within the context of a TUBITAK (Turkish Research Council) Project (no: 116Y127). Fieldwork in Oman for EÖ and IAA was supported by Sultan Qaboos University (Project No: IG/SCI/ETHS/18/03). We thank Lorenzo Consorti (Trieste) and Esmeralda Caus (Barcelona) for their reviews that helped to improve this contribution. Aral Okay acknowledges support from Turkish Academy of Sciences (TÜBA). Mike Bidgood provided useful critical comments. This pape is dedicated to Dr. Engin Meriç (İstanbul), the author of many important contributions on the Late Cretaceous benthic foraminifera of Turkey.

\section{Authors' contributions}

EÖ: conceptualization, methodology, investigation, sampling in Turkey and Oman, supervision, and writing original draft. AOY: sampling in Turkey, investigation, and resources. RC: investigation (study of calcareous nannofossils) and visualisation. SK: investigation (study of larger forams). AIO: field work in Central Sakarya Basin and sample collection. MDS: conceptualization and writing original draft. JP: conceptualization and writing original draft. IAA: sampling in Oman. ÜE: sampling in Central Sakarya Basin. All the authors read and approved the final manuscript.

\section{Funding}

This work was supported by TUBITAK (Turkish Research Council) Project (no: 116Y127) and by Sultan Qaboos University (Oman) (Project No: IG/SCI/ ETHS/18/03).

\section{Availability of data and materials}

All thin sections and oriented sections are deposited in the Palaeontology Section of the Department of Geological Engineering (İstanbul Technical University).

\section{Declarations}

Competing interests

We report no potential conflict of interest.

\section{Author details}

${ }^{1}$ Department of Geological Engineering, Faculty of Mines, İstanbul Technical University (ITU), Maslak, 34469 İstanbul, Turkey. ${ }^{2}$ Istituto di Geoscienze e Georisorse CNR, 56124 Pisa, Italy. ${ }^{3}$ Department of Geological Engineering, Faculty of Engineering, Fırat University, Elazığ, Turkey. ${ }^{4}$ Istanbul Technical University, Eurasia Institute of Earth Sciences, İstanbul 34469, Turkey. ${ }^{5}$ Halliburton, 97 Milton Park, Abingdon OX14 4RW, UK. ${ }^{6}$ Dipartimento di Scienze della Terra, Università degli Studi di Roma "La Sapienza", Rome, Italy. ${ }^{7}$ Department of Earth Sciences, Sultan Qaboos University (SQU), Muscat, Sultanate of Oman.

${ }^{8}$ Department of Earth Sciences, Freie Universität Berlin, Berlin, Germany.

Received: 25 November 2020 Accepted: 25 February 2021

Published online: 19 April 2021

\section{References}

Abdelghany, O. (2003). Late Campanian-Maastrichtian foraminifera from the Simsima Formation on the western side of the northern Oman Mountains. Cretaceous Research, 24, 391-405.

Albrich, S., Frijia, G., Parente, M., \& Caus, E. (2014). The evolution of the earliest representatives of the genus Orbitoides: implications for the Upper Cretaceous biostratigraphy. Cretaceous Research, 51, 22-34.

Altıner, D., Koçyiğit, A., Farinacci, A., Nicosia, U., \& Conti, M. A. (1991). JurassicLower Cretaceous stratigraphy and paleogeographic evolution of the southern part of north-western Anatolia (Turkey). Geologica Romana, 27, $13-80$.

Barrier, E., Vrielynck, B., Brouillet, J.-F., \& Brunet, M.-F. (2018). Atlas of Paleotectonic reconstruction of the Central Tethyan Realm. Tectono-sedimentary-palinspastic maps from late Permian to Pliocene.

Baumfalk, Y. A. (1986). The evolution of Orbitoides media (Foraminiferida) in the Late Campanian. The Journal of Foraminiferal Research, 16, 293-312.

Baumfalk, Y. A., \& Willemsen, F. (1986). Ecophenotypic variation of the larger foraminifer Orbitoides apiculata from the Maastrichtian stratotype. Netherlands Journal of Geosciences, 65, 23-34.

Béchennec, F., Roger. J., Janjou, D., Le Métour, J., Wyns, R., \& Beurrier, M. (1993). Geological map of Mahdah, Sheet NG 40-14D2, Scale 1:50000, with Explanatory Notes. Directorate General of Minerals, Oman Ministry of Petroleum and Minerals, 46.

Bown, P. R., \& Young, J. R. (1998). Techniques. In P. R. Bown (Ed.), Calcareous nannofossil biostratigraphy (pp. 16-28). British Micropalaeontology Society Publication Series.

Burnett, J. A. (1998). Upper Cretaceous. In P. R. Bown (Ed.), Calcareous Nannofossil Biostratigraphy (pp. 132-199). British Micropalaeontological Society Publication Series.

Caus, E., Bernaus, J. M., \& Gomez-Garrido, A. (1996). Biostratigraphic utility of species of the genus Orbitoides. The Journal of Foraminiferal Research, 26, 124-136.

Chiocchini, M., Pampaloni, M. L., \& Pichezzi, R. M. (2012). e microfossili delle successioni carbonatiche mesozoiche del Lazio e dell'Abruzzo (Italia centrale)—Cretacico. Mem. per servire Descr. della Carta Geol. d'It., ISPRA, Serv. Geol. d'It.- Dip. Dif. Suolo 17, 1-269., Roma. 
Drooger, C.W. (1983). Environmental gradients and evolutionary events in some larger foraminifera. In: J. E. Meulenkamp (Ed.), Reconstruction of marine paleoenvironments. Utrecht Micropaleontological Bulletins 30:255-271.

Drooger, C. W. (1993). Radial Foraminifera; morphometrics and evolution. Verhandelingen der Koninklijke Nederlandse Akademie van Wetenschappen, Afdeling Natuurkunde, 41, 1-242.

Eggink, J. W., \& Baumfalk, Y. A. (1983). The exceptional reproduction and embryonic morphology of Orbitoides gensacicus (Late Cretaceous, S. France). The Journal of Foraminiferal Research, 13, 179-190.

Erdem, M. E., Özcan, E., Yücel, A. O., Okay, A. I., Erbay, S., Kayğılı, S., \& Yılmaz, I. (2021). Late Campanian larger benthic foraminifera from the Zekeriyaköy Formation (İstanbul, NW Turkey): taxonomy, stratigraphy and paleogeography. Turkish Journal of Earth Sciences, 30, 1-21.

Glennie, K. W., Bouef, M. G. A., Hughes-Clarke, M. W., Moody-Stuart, J., Pilaar, W. F. H. \& Reinhardt, B. M. (1974). Geology of the Oman Mountains. Verhandelingen van het Koninklijk Nederlands Geologisch Mijnbouwkundig Genootschap 31 (3 volumes):423 pp.

Goldbeck E.J. (2007). Faunal provinces and patterns of diversity in Late Cretaceous (Santonian-Maastrichtian) larger foraminifera. PhD thesis, Rheinische Friedrich-Wilhelms-Universität Bonn 8:276 pp.

Goldbeck, E. J., \& Langer, M. R. (2009). Biogeographic provinces and patterns of diversity in selected Upper Cretaceous (Santonian-Maastrichtian) larger foraminifera. Geologic Problem Solving with Microfossils: A volume in Honor of Garry D. Jones. SEPM Special Publication 93:187-232.

Görmüş, M., \& Meriç, E. (2000). Unusual forms of orbitoidal foraminifera in the Maastrichtian of Turkey. Cretaceous Research, 21, 801-812.

Kayğılı, S., Yücel, A. O., Abbasi, İ. A., Catanzariti, R., \& Özcan, E. (2021). A new species of Omphalocyclus Bronn, O. omanensis sp. nov., from the upper Campanian of Oman: phylogenetic and stratigraphic implications. Cretaceous Research. https://doi.org/10.1016/j.cretres.2021.10480.

Less, Gy., \& Kovács, Ó. L. (2009). Typological versus morphometric separation of orthophragminid species in single samples - a case study from Horsarrieu (upper Ypresian, SW Aquitaine, France). Revue de Micropaléontologie, 52, 267-288.

Loeblich, A. R., \& Tappan, H. (1987). Foraminiferal genera and their classification (p. 970). Van Nostrand Reinhold Company.

Maden Tetkik ve Arama Genel Müdürlüğü. (2011). 1: 1250000 scale geological map of Turkey. Ankara, Turkey.

Meriç, E. (1965). Etude géologique et paléontologique de la région entre Kahta et Nemrut Dağ (Sud-Est Anatolie). Istanbul Üniversitesi Fen Fakültesi Mecmuası, Seri B., 30(1-2), 55-107.

Meriç, E. (1974). Orbitoides apiculata Schlumberger pamiri n. spp. du Maestrichtien superieur du Taurus Lycien (Turquie). Revista Española de Micropaleontología, 6, 135-144.

Meriç, E., Oktay, F. Y., Toker, V., Tansel, İ, \& Duru, M. (1987). Sedimentary geology and biostratigraphy (foraminifer, nannoplankton and ostracod) of the Upper Cretaceous-Eocene sequence in the Adıyaman area, southeast Turkey. Geological Bulletin of Turkey, 30, 19-32.

Métour, J., Béchennec, F., Chevremont, P., Roger, J., Wyns, R. (1992). Geological map of Buraymi, Sheet NG 40-14, Scale 1 250,000, with Explanatory Notes. Directorate General of Minerals, Oman Ministry of Petroleum and Minerals, 89.

Mitchell, S. F. (2005). Biostratigraphy of Late Maastrichtian larger foraminifers in Jamaica and the importance of Chubbina as a late Maastrichtian index fossil. Journal of Micropalaeontology, 24, 1-8.

Neumann, M. (1972). A propos des Orbitoïdides du Crétacé supérieur et de leur signification stratigraphique. I. Genre Orbitoides d'Orbigny (1847). Revue de Micropaléontologie, 14, 197-226.

Neumann, M. (1987). Le genre Orbitoides. I. Réflexions sur les espèces primitives attribuées à ce genre. Revue de Micropaléontologie, 29, 220-261.

Nolan, S. C., Skelton, P. W., Clissold, P., \& Smewing, J. D. (1990). Maastrichtian to early Tertiary stratigraphy and palaeogeography of the central and northern Oman Mountains. The geology and tectonics of the Oman region. Geological Society, London, Special Publications, 49, 495-519.

Ocakoğlu, F., Hakyemez, A., Açıkalın, S., Özkan Altıner, S., Büyükmeriç, Y., Licht, A., Demircan, H., Safak, Ü., Yıldız, A., Yılmaz, IÖ., Wagreich, M., \& Campbell, C. (2019). Chronology of subduction and collision along the Izmir-Ankara suture in Western Anatolia: records from the Central Sakarya Basin. International Geology Review, 61, 1244-1269.

Odin, G. S., \& Lamaurelle, M. A. (2001). The global Campanian-Maastrichtian stage boundary. Episodes, 24(4), 229-238.
Okay, A.I., \& Tüysüz, O. (1999). Tethyan sutures of northern Turkey. In B. Durand, L. Jolivet, F. Horvwáth \& M. Séranne (Eds.), The Mediterranean Basins: Tertiary extension within the Alpine Orogen. Geological Society, London, Special Publications 156, 475-515.

Özcan, E. (1993). Late Cretaceous benthic foraminiferal proliferation on the Arabian platform: taxonomic remarks on the genus Orbitoides d'Orbigny, 1848. Geological Journal, 28, 309-317.

Özcan E. (1994). Stratigraphic and foraminiferal micropaleontology of the upper Cretaceous sedimentary succession in the NE Kahta (Adıyaman) region: A biometric approach to orbitoidal foraminifera. 329 p., PhD Thesis, Middle East Technical University, Ankara.

Özcan, E. (1995). Evaluation of the nepionic chamber arrangement in Lepidorbitoides bisambergensis (Jaeger, 1914), Early Maastrichtian, SE Turkey. Revue de Paléobiologie, 14, 195-208.

Özcan, E. (2007). Morphometric analysis of the genus Omphalocyclus from the late Cretaceous of Turkey: new data on its stratigraphic distribution in Tethys and description of two new taxa. Cretaceous Research, 28, 621-641.

Özcan, E., Hakyemez, A., Çiner, A., Okay, A. I., Soussi, M., Boukhalfa, K., \& Yücel, A. O. (2020). Reassessment of the age and depositional environments of the Eocene Cayraz Formation; a reference unit for the Tethyan larger benthic foraminifera (Haymana Basin, Central Turkey). Journal of Asian Earth Sciences, 193, 104304.

Özcan, E., \& Özkan-Altıner, S. (1997). Late Campanian-Maastrichtian evolution of orbitoidal foraminifera in Haymana Basin succession (Ankara, Central Turkey). Revue de Paléobiologie, 16, 271-290.

Özcan, E., \& Özkan-Altıner, S. (1999). The genera Lepidorbitoides and Orbitoides: evolution and stratigraphic significance in some Anatolian basins. Geological Journal, 34, 275-286.

Özcan, E., van Gorsel, J. T., Sarı, B., Yücel, A. O., Erbay, S., \& Okay, A. I. (2019). Primitive Helicorbitoides (Foraminifera) and associated larger benthic foraminifera from the Campanian Tonya Formation, Trabzon, eastern Pontides, NE Turkey. Cretaceous Research, 101, 30-42.

Özcan, E., Yücel, A. O., Abbasi, İ. A., Catanzariti, R., \& Kayğılı, S. (2021). Larger benthic foraminifera from the Maastrichtian Simsima Formation at Buraymi region: morphometry and paleobiogeographic results.

Özer, S. (1986). Faune de Rudistes Maestrichtienne de l'environ de KahtaAdıyaman (Anatolie Sud-Est). Bulletin of the Mineral Research and Exploration, 107, 101-105.

Özer, S., Meriç, E., Görmüş, M., \& Kanbur, S. (2009). Biogeographic distribution of rudists and benthic foraminifera: An approach to Campanian-Maastrichtian palaeobiogeography of Turkey. Geobios, 42, 623-638.

Payandeh, S., Afghah, M., \& Shirazi, M. P. (2019). Biostratigraphy and lithostratigraphy of Tarbur Formation (Upper Cretaceous) in Hossein Abad section, Zagros Basin (SW of Iran). Carbonate and Evaporites, 34, 931-939.

Perch-Nielsen, K. (1985). Mesozoic calcareous nannofossils. In H. M. Bolli, J. B. Saunders, \& K. Perch-Nielsen (Eds.), Plankton Stratigraphy (pp. 329-427). Cambridge University Press.

Perinçek, D. (1980). Sedimentation on the Arabian shelf under the control of tectonic activity in Taurid belt. Proceedings of the 5th Petroleum Congress and Exhibition of Turkey, Turkish Association of Petroleum Geol Pub, 77-93

Pignatti, J. (1998). The philosophy of larger foraminiferal biozonation-A discussion. Dela Opera SAZU Razr, 4(34), 15-20.

Rahaghi, A. (1976). Contribution à l'étude de quelques grand foraminifères de I'Iran. Parts 1-3. Société National Iranienne des Pétroles, Laboratoire de Micropaléontologie, Publication 6: 79.

Rigo de Righi, M., \& Cortesini, A. (1964). Gravity tectonics in the foothills structure belt of Southeast Turkey. American Association of Petroleum Geologists Bulletin, 48, 1911-1937.

Roger, J., Béchennec, F., Janjou, D., Le Métour, J. (1993). Geological map of Al Buraymi, Sheet NG 40-14D4, Scale 1 50000, with Explanatory Notes. Directorate General of Minerals, Oman Ministry of Petroleum and Minerals, 49.

Roth, P. H. (1978). Cretaceous nannoplankton biostratigraphy and oceanography of the northwestern Atlantic Ocean. In: W. E. Benson, R. E. Sheridan et al. (Eds.), Initial Reports of the Deep Sea Drilling Project 44, 731-759.

Saner, S. (1980). The paleogeographical interpretation of the Mudurnu-Göynük Basin based on the depositional features of the Jurassic and later ages. Geological Bulletin of Turkey, 23, 39-52. (In Turkish).

Schlagintweit, F., Rashidi, K., \& Barani, F. (2016). First record of Gyroconulina columellifera Schroeder \& Darmoian, 1977 (larger benthic foraminifera) from the Maastrichtian Tarbur Formation of SW Iran (Zagros Fold-ThrustBelt). Geopersia, 6, 169-185. 
Schlüter, M., Steuber, T., Parente, M., \& Mutterlose, J. (2008). Evolution of a Maastrichtian-Paleocene tropical shallow-water carbonate platform (Qahlat, NE Oman). Facies, 54, 513-527.

Sissingh, W. (1977). Biostratigraphy of Cretaceous calcareous nannoplankton. Netherlands Journal of Geosciences, 56, 37-65.

Skelton, P. W., Nolan, S. C., \& Scott, R. W. (1990). The Maastrichtian transgression onto the northwestern flank of the proto-Oman mountains: sequences of rudist-bearing beach to open shelf facies. In A. H. F. Searle \& A. C. Ries (Eds.), The Geology and Tectonics of the Oman Region, 49 (pp. 521-547). Geological Society, London, Special Publications.

van Gorsel, J. T. (1978). Late Cretaceous orbitoidal foraminifera. In R. G. Hedley \& C. G. Adams (Eds.), Foraminifera 3 (pp. 1-120). Academic Press.

van Hinte, J. E. (1965). An approach to Orbitoides. Proceedings of the Koninklijke Nederlandse Akademie Van Wetenschappen, Series B, 68, 57-70.

van Hinte, J. E. (1966a). Orbitoides hottingeri n. sp. from northern Spain. Proceedings of the Koninklijke Nederlandse Akademie Van Wetenschappen, Series $B, 69,388-402$. van Hinte, J. E. (1966b). Orbitoides from the Campanian type section. Proceedings of the Koninklijke Nederlandse Akademie Van Wetenschappen, Series B, 69, 79-109.

van Hinte, J. E. (1968). The Late Cretaceous larger foraminifer Orbitoides douvillei (Silvestri) at its type-locality Belves, SW France. Proceedings of the Koninklijke Nederlandse Akademie Van Wetenschappen, Series B, 71, 359-372.

van Hinte, J. E. (1976). A Cretaceous time scale. American Association of Petroleum Geologists Bulletin, 60, 498-516.

YIlmaz, Y. (1993). New evidence and model on the evolution of the southeast Anatolian orogen. Geological Society of America Bulletin, 105, 252-271.

\section{Publisher's Note}

Springer Nature remains neutral with regard to jurisdictional claims in published maps and institutional affiliations.

\section{Submit your manuscript to a SpringerOpen ${ }^{\odot}$ journal and benefit from:}

- Convenient online submission

- Rigorous peer review

- Open access: articles freely available online

- High visibility within the field

- Retaining the copyright to your article

Submit your next manuscript at $\mathbf{s p r i n g e r o p e n . c o m ~}$ 